\title{
Impact of the introduced predator, Laricobius nigrinus, on ovisacs of the overwintering generation of hemlock woolly adelgid in the eastern United
}

\section{States}

\author{
Carrie S. Jubb ${ }^{\mathrm{a}, *}$, Ariel R. Heminger ${ }^{\mathrm{a}, 1}$, Albert E. Mayfield III ${ }^{\mathrm{b}}$, Joseph S. Elkinton ${ }^{\mathrm{c}}$, \\ Gregory J. Wiggins ${ }^{\mathrm{d}, 2}$, Jerome F. Grant ${ }^{\mathrm{d}}$, Jeffrey A. Lombardo ${ }^{\mathrm{c}, 3}$, Thomas J. McAvoy ${ }^{\mathrm{a}}$, \\ Ryan S. Crandall ${ }^{c}$, Scott M. Salom ${ }^{\mathrm{a}}$ \\ ${ }^{a}$ Virginia Tech, Department of Entomology, Price Hall, Room 216A, 170 Drillfield Drive, Blacksburg, VA 24061, USA \\ ${ }^{\mathrm{b}}$ USDA Forest Service, Southern Research Station, 200 W.T. Weaver Boulevard, Asheville, NC 28804, USA \\ ${ }^{c}$ University of Massachusetts, Department of Environmental Conservation, Amherst, MA 01003, USA \\ ${ }^{\mathrm{d}}$ University of Tennessee, Department of Entomology and Plant Pathology, 2505 E. J. Chapman Drive, Knoxville, TN 37996, USA
}

\section{A R T I C L E I N F O}

\section{Keywords:}

Biological control

Adelges tsugae

Laricobius nigrinus

Predator

Impact

Tsuga canadensis

\begin{abstract}
A B S T R A C T
Hemlock woolly adelgid (HWA), Adelges tsugae Annand (Hemiptera: Adelgidae), is an invasive pest causing significant mortality to eastern and Carolina hemlock in eastern North America. Since 2003, management of HWA has included targeted release of the HWA predator Laricobius nigrinus Fender (Coleoptera: Derodontidae), native to western North America. Establishment of L. nigrinus at release sites is well documented, but investigations of its impact on HWA populations have been limited. A four-year (2014-2018), two-phase study using predator exclusion cages to assess the impact of $L$. nigrinus on HWA was conducted at nine previous release sites in the eastern United States. Significantly more HWA sistens ovisacs were disturbed on no-cage and opencage branches than on caged branches where predators were excluded. Mean disturbance levels on cage, no-cage and open-cage branches was 8,38 , and 27 percent, respectively. Seven of nine sites had a mean HWA ovisac disturbance greater than $50 \%$ for at least one year. Winter temperatures were also a significant factor in overall mortality of the sistens generation with a mean of $46 \%$ on study branches. Six of nine sites had a mean overall mortality (winter mortality and predation) greater than $80 \%$ for at least one year. Larvae of Laricobius spp. were recovered at all sites during this study. Sequencing of the COI gene from recoveries in Phase One (2015 and 2016 ) indicated that $88 \%$ were $L$. nigrinus and $12 \%$ were $L$. rubidus LeConte. Microsatellite analysis performed during Phase Two (2017 and 2018) indicated that approximately $97 \%$ of larval recoveries were L. nigrinus, $2 \%$ were hybrids of $L$. nigrinus and $L$. rubidus, and $1 \%$ were $L$. rubidus. Results of this study suggest that $L$. nigrinus can significantly impact the HWA sistens generation ovisacs and continued investment in the use of this species as a biological control is recommended.
\end{abstract}

\section{Introduction}

Two native hemlock species in the eastern United States, eastern hemlock (Tsuga canadensis (L.) Carriere) and Carolina hemlock (Tsuga caroliniana Engelm), are currently threatened by the invasive insect, hemlock woolly adelgid (HWA), Adelges tsugae Annand (Hemiptera: Adelgidae). The first detection of HWA in eastern North America was in Richmond, VA where it likely arrived sometime prior to 1951 on nursery stock (Havill et al., 2006). Since its accidental introduction, HWA has spread throughout a significant portion of the native range of

\footnotetext{
* Corresponding author.

E-mail addresses: cjubb@vt.edu (C.S. Jubb), arielrh@vt.edu (A.R. Heminger), albert.e.mayfield@usda.gov (A.E. Mayfield), elkinton@ent.umass.edu (J.S. Elkinton), wiggybug@utk.edu (G.J. Wiggins), jgrant@utk.edu (J.F. Grant), jalombardo@smcm.edu (J.A. Lombardo), tmcavoy@vt.edu (T.J. McAvoy), salom@vt.edu (S.M. Salom).

${ }^{1}$ Current address: Virginia Tech, School of Plant and Environmental Sciences, 220 Smyth Hall, 185 Ag Quad Lane, Blacksburg, VA 24061

${ }^{2}$ Current address: University of Tennessee, National Institute for Mathematical and Biological Synthesis, 1122 Volunteer Boulevard, Suite 106, Knoxville, TN 37996, USA

${ }^{3}$ Current address: St. Mary's College of Maryland, Department of Biology, 236 Schaefer Hall, St. Mary's City, MD 20686, USA
} 
eastern hemlock. HWA is endemic to Asia and western North America and is associated with the nine other hemlock species worldwide (Havill et al., 2016). Populations in the native range, however, remain at innocuous levels due to the co-evolution of resistance in host trees, and an assemblage of associated natural enemies (Cheah and McClure, 1995; McClure and Cheah, 1999).

HWA has an anholocyclic life cycle in eastern North America, with two distinct asexual generations per year: a long over-wintering sistens generation which has a period of summer aestivation, and a shorter, spring progrediens generation (Havill and Foottit, 2007; McClure, 1989). Although HWA is primarily a sessile species, "crawlers", or first instar nymphs of each generation disperse and settle at the base of hemlock needles. They feed on plant nutrients by inserting their stylet bundles into hemlock xylem ray parenchyma cells (McClure, 1987; Young et al., 1995) which can then lead to tree mortality (McClure, 1991; Orwig et al., 2002). Both generations of HWA secrete a waxy flocculence (ie., "wool") which functions as an ovisac for gravid adults.

Current management of HWA in forest settings involves a suite of tactics. Chemical control, including the use of neonicotinoid insecticides, has been an important and effective component of overall management efforts (Benton et al., 2015; Cowles et al., 2006). Additional techniques currently in development include silvicultural practices (Brantley et al., 2017), resistance breeding (Montgomery et al., 2009) and gene conservation (Jetton et al., 2013), however; classical biological control has received significant focus within HWA management efforts in the forest setting (Onken and Reardon, 2011).

Early studies investigating potential natural enemies of HWA in the introduced range of the eastern U.S. indicated that although present, predators were often generalists and did not manage HWA populations to levels that would prevent hemlock mortality (Wallace and Hain, 2000). The most abundant predator found in association with HWA on hemlock during surveys in the native range of western North America was Laricobius nigrinus Fender (Coleoptera: Derodontidae) found in coastal populations of hemlock (ie., coastal strain) (Kohler et al., 2008). Evaluations of $L$. nigrinus under quarantine indicated that this species was univoltine (Zilahi-Balogh et al., 2003) and highly host-specific to HWA (Zilahi-Balogh et al., 2002), with both species having a coinciding summer aestivation. Laricobius nigrinus, like other species in the genus, is known to be a specialist of the family Adelgidae and is therefore a major focus of biological control efforts (Lamb et al., 2011). Adult $L$. nigrinus feed on nymphs and adult HWA, while larvae feed primarily on eggs of HWA (Zilahi-Balogh et al., 2003). Laricobius rubidus LeConte is native to eastern North American, and its primary host is pine bark adelgid (PBA), Pineus strobi Hartig (Hemiptera: Adelgidae) on white pine (Pinus strobus L.) (Clark and Brown, 1960; Wantuch et al., 2019). When white pine and hemlock co-occur in forests, L. rubidus can be found feeding and completing development on HWA (Zilahi-Balogh et al., 2005). Laricobius nigrinus and L. rubidus are sister species which have a recent divergence from a common ancestor and are capable of reproducing with each other. Resulting hybrid offspring are reproductively viable (Fischer et al., 2015; Havill et al., 2012).

The first operational releases of the coastal strain of $L$. nigrinus began in 2003 and since then, over 400,000 beetles have been released from field and laboratory sources (Virginia Tech, 2019). The ability of L. nigrinus to successfully establish and disperse from select release sites is well documented (Davis et al., 2012; Foley et al., 2019; Mausel et al., 2010), but efforts to characterize the impact of L. nigrinus on HWA populations have been few and limited in spatial scope (Mausel et al., 2008; Mayfield et al., 2015). To help inform future management decisions regarding HWA biological control, this study evaluated the impact of $L$. nigrinus on the HWA sistens generation and their ovisacs at several sites in the eastern U.S. where the predator has been established for multiple years. Predator exclusion cages were used to monitor both HWA and $L$. nigrinus populations and therefore quantify the impact of $L$. nigrinus on HWA. Since common generalist predators of HWA, such as Harmonia axyridis Pallas (Coleoptera: Coccinellidae), generally become
Table 1

Sites, locations, USDA Plant Hardiness Zones, and year of release of Laricobius nigrinus for nine study sites used to evaluate the impact of $L$. nigrinus on hemlock woolly adelgid in the eastern U.S.

\begin{tabular}{llll}
\hline Site & Location Coordinates & Plant Hardiness Zone ${ }^{\mathrm{a}}$ & Release Year \\
\hline NJ1 & $41.12 \mathrm{~N},-74.91 \mathrm{~W}$ & $6 \mathrm{a}$ & 2007,2008 \\
MD1 & $39.70 \mathrm{~N},-78.67 \mathrm{~W}$ & $6 \mathrm{~b}$ & 2004 \\
VA1 & $37.64 \mathrm{~N},-78.80 \mathrm{~W}$ & $7 \mathrm{a}$ & 2005 \\
VA2 & $37.21 \mathrm{~N},-80.59 \mathrm{~W}$ & $6 \mathrm{~b}$ & 2003 \\
NC1 & $35.82 \mathrm{~N},-82.21 \mathrm{~W}$ & $6 \mathrm{~b}$ & 2005 \\
TN1 & $35.76 \mathrm{~N},-83.30 \mathrm{~W}$ & $7 \mathrm{a}$ & 2007 \\
TN2 & $35.69 \mathrm{~N},-83.87 \mathrm{~W}$ & $7 \mathrm{a}$ & 2008 \\
TN3 & $35.66 \mathrm{~N},-83.59 \mathrm{~W}$ & $7 \mathrm{a}$ & 2006 \\
GA1 & $34.79 \mathrm{~N},-83.76 \mathrm{~W}$ & $7 \mathrm{~b}$ & 2008,2010 \\
\hline
\end{tabular}

a Plant Hardiness Zones are based on average annual minimum temperature and acquired from planthardiness.ars.usda.gov. 6a $\left(-23.3\right.$ to $\left.-20.5^{\circ} \mathrm{C}\right), 6 \mathrm{~b}$ $\left(-20.6\right.$ to $\left.-17.8^{\circ} \mathrm{C}\right)$, $7 \mathrm{a}\left(-17.8\right.$ to $\left.-15^{\circ} \mathrm{C}\right)$ and $7 \mathrm{~b}\left(-15\right.$ to $\left.-12.2^{\circ} \mathrm{C}\right)$.

active later in the spring after the period of this study (Koch, 2003), we were able to specifically measure $L$. nigrinus predation. The study reported here occurred in two phases. Phase One was conducted from Fall 2014 to Spring 2016 and was affected by two polar vortex events that caused extreme low winter temperatures in January 2014 and February 2015. Those temperatures caused high mortality of both HWA and $L$. nigrinus populations at the study sites prior to and during this phase. Therefore, the study was extended for a second phase (Fall 2016 to Spring 2018) to provide an extended evaluation of HWA and predator population dynamics over time.

\section{Materials and methods}

\subsection{Field site and study tree selection}

Nine field sites in six states (Georgia, Maryland, New Jersey, North Carolina, Tennessee) were selected and utilized in both Phase One and Two of the study (Table 1, Fig. 1). Each site occurred within one of the following four USDA Plant Hardiness Zones that reflect average annual minimum temperatures experienced in the past 30 years (Table 1): $6 \mathrm{a}$ $\left(-23.3\right.$ to $\left.-20.5^{\circ} \mathrm{C}\right), 6 \mathrm{~b}\left(-20.6\right.$ to $\left.-17.8^{\circ} \mathrm{C}\right), 7 \mathrm{a}\left(-17.8\right.$ to $\left.-15^{\circ} \mathrm{C}\right)$ and 7b $\left(-15\right.$ to $-12.2^{\circ} \mathrm{C}$ ) (USDA, 2012). Site selection criteria were threefold. First, initial releases of $L$. nigrinus were made at least four years prior to the initiation of the study in 2014. Second, recoveries of $L$. nigrinus at these sites were made multiple years after the initial release which suggested this species had established. Finally, HWA densities were moderate to heavy $(2-3 \mathrm{HWA} / \mathrm{cm})$ to allow for adequate prey populations to examine predation.

\subsection{Fall Assessment: Initial HWA densities and treatment set-up}

Each year in October or early November, study trees and branches were selected, and HWA densities were quantified after the HWA sistens generation had broken summer aestivation and began developing. During this time, adult $L$. nigrinus was emerging from its aestivation period in the soil and was migrating to hemlock to begin feeding on HWA. Tsuga canadensis trees were selected based on the presence of branches containing approximately 2-3 HWA/cm; when these densities were not present, trees with the highest densities available were chosen. The number of trees selected per site varied from 5 to 15 , and some trees hosted multiple sets of branch treatments. At each site, 15 pairs of $1 \mathrm{~m}$ long branches (30 total) were identified, and segments approximately $20-30 \mathrm{~cm}$ long (two segments in Phase One, and one segment in Phase Two) on each of these branches were tagged for future measurements. Branches were tapped approximately 10 times to dislodge and remove any Laricobius adults present. HWA densities on branches were estimated in the field by counting the number of woolly HWA nymphs developing on new growth and dividing by the total length of 


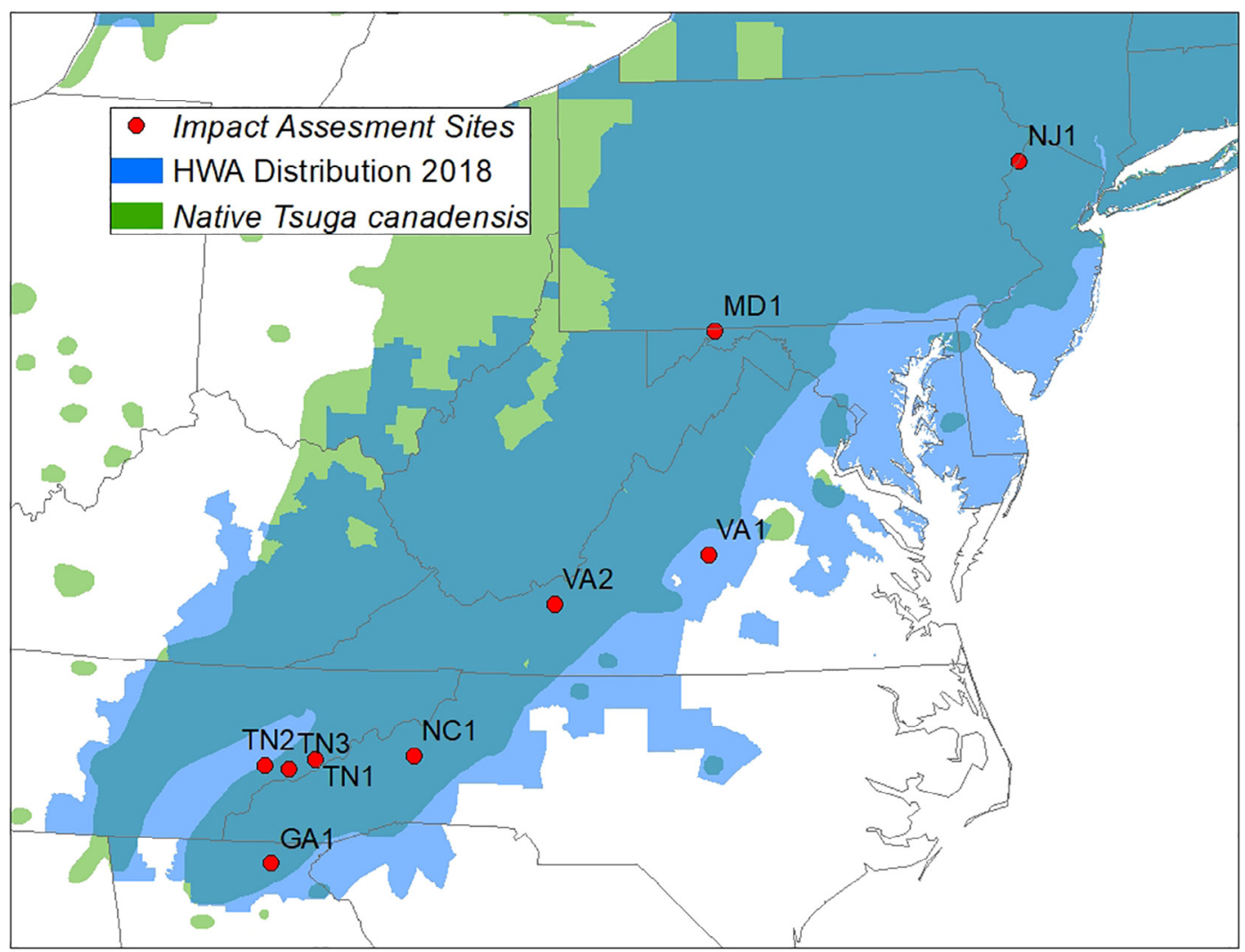

Fig. 1. Locations of nine study sites (red dots) used in an impact assessment of Laricobius nigrinus on HWA in the eastern U.S., native range of Tsuga canadensis (indicated in blue), and HWA distribution (indicated in green). Adapted from 'Distribution of HWA in 2018', USDA Forest Service, 2019, http://hwa.ento.vt.edu/ hwa/wp-content/uploads/2019/03/HWA2018.pdf.

new growth to obtain the number of HWA per $\mathrm{cm}$.

Following these measurements, treatments were randomly assigned to branches within each pair. The first treatment was an open branch (no-cage) which was completely exposed to HWA predators. The second treatment was a branch fully enclosed within a predator exclusion cage constructed of nylon mesh and measuring $1 \mathrm{~m}$ in length (with mesh size ca. $104 \times 94$ and ca. $300 \mu \mathrm{m}$ aperture). During Phase One, five additional branches were assigned an "open cage" treatment at all sites except NJ1 (2014 and 2015) and NC1 (2015) to account for possible cage effects. In this treatment, a predator exclusion cage was applied to the branch, but was left open to allow free movement of predators in and out of the cage. No open cage effects were observed during Phase One, so this treatment was excluded in Phase Two. Cages were secured to branches using zip ties to cinch the open end of the bag over a $7.5 \mathrm{~cm}$ section of $1.27 \mathrm{~cm}$ thick foam pipe insulation placed around the branch (Thermwell Products Co. Inc., Mahwah, NJ, USA). Branches then remained in the field for ca. four to five months to allow both HWA and Laricobius spp. to feed, develop, and oviposit. In 2017, hemlocks at site TN2 did not support adequate populations of HWA and was therefore not utilized.

\subsection{Winter assessment (Phase One only): Adult Laricobius spp. predation of HWA sistens generation and HWA winter mortality}

In Phase One only, a winter assessment of adult Laricobius spp. predation of HWA sistens ovisacs and of HWA sistens winter mortality was made during February or early March. This assessment corresponded with the period of peak HWA sistens generation oviposition when approximately $75 \%$ or greater of the HWA were producing eggs. One previously tagged $20-30 \mathrm{~cm}$ long branch segment was clipped from each treatment branch, placed into a $3.8 \mathrm{~L}$ plastic zip closure bag, and transported to laboratory facilities for further analysis. Branch segments were evaluated under a dissecting microscope and the number of (1) intact ovisacs that contained live HWA, (2) winter-killed HWA, and (3) HWA disturbed or preyed upon were counted. Adelgids with intact wool that produced red hemolymph when pressure was applied using a straight tip teasing needle were considered alive and their ovisacs were counted as undisturbed. Adelgids within undisturbed HWA ovisacs that were reduced in size, shriveled, and hard when probed with a straight tip teasing needle were counted as dead due to winter temperatures. The reduced size of these adelgids indicated that mortality occurred while in an earlier instar. Percent winter mortality was calculated as the total number of winter-killed adelgid divided by the total number of adelgid (live + dead) on the branch. Adelgids with ovisacs that had a shredded appearance were considered preyed upon and were counted as disturbed. Undisturbed wool that surrounds an adult HWA and its ovisac is compact and circular. Predation of HWA ovisacs by Laricobius spp. larvae causes the wool to become frayed and often displaced from the branch. HWA eggs originally contained within ovisacs are often completely consumed by Laricobius spp. larvae and those that remain may desiccate as a result of this disturbance and, therefore, may not hatch. This type of feeding is consistent with the genus Laricobius as noted in Brown and Clark (1962), and has been used as a proxy for Laricobius spp. predation in several prior studies (Lamb et al., 2005b; Mausel et al., 2017; Mausel et al., 2008; Mayfield et al., 2015; Vieira et al., 2011; Vieira et al., 2013). Percent ovisac disturbance was calculated as the total number of ovisacs disturbed divided by the total number of adelgid (live + dead) on the branch. HWA winter mortality and ovisac disturbance were quantified separately, with the exception of sites MD1, VA1, and VA2 in 2015, when the two variables were recorded in aggregate due to researcher error and were reported as overall mortality. The winter assessment was eliminated in Phase Two due to minimal evidence of adult Laricobius predation in Phase One and the ability to capture winter mortality during the spring assessment 
(described below).

\subsection{Spring Assessment: HWA winter mortality (Phase Two only) and cumulative predation of HWA by adult and larval Laricobius spp.}

A final assessment was performed beginning in March or April, during peak $L$. nigrinus oviposition and when $L$. nigrinus larvae were first present on branches. This assessment quantified 1) cumulative predation of HWA ovisacs by adult and larval $L$. nigrinus, 2) densities of Laricobius larvae present on study branches, and 3) winter mortality of the HWA sistens generation (Phase Two only). Previously tagged $20-30 \mathrm{~cm}$ branch segments were clipped from each branch and transported to laboratory facilities as described above for the winter assessment. In the laboratory, the cut ends were inserted into saturated blocks of Instant Deluxe Floral Foam (Smithers-Oasis North America, Kent, $\mathrm{OH}$ ) wrapped in Parafilm M (Beemis N.A., Neemah, WI). Blocks containing the study branches were then placed into funnels or other structures modified for Laricobius spp. larval rearing (Mayfield et al., 2015; Salom et al., 2012). Branches were held at $13-15^{\circ} \mathrm{C}$ and a $12 \mathrm{~h}: 12: \mathrm{h}$ (L:D) cycle, which are environmental conditions appropriate for developing $L$. nigrinus larvae (Lamb et al., 2005a; Salom et al., 2012). In Phase One, samples from MD1, VA1, and VA2 were enclosed in an outdoor structure and unheated storage building due to a lack of adequate space within laboratory rearing facilities. These samples were exposed to ambient local temperatures and filtered light conditions during larval feeding and development.

Funnels were monitored for approximately 4-6 weeks to allow any Laricobius spp. larvae present on study branches to feed and develop through four instars. At maturity, Laricobius spp. larvae dropped from branches into a collection container placed at the bottom of each larval rearing structure. Collection arenas were checked every 1-2 days until no further larvae were observed. All larvae were preserved in vials containing $95 \%$ EtOH to allow for genetic analysis to identify species or hybrids. On rare occasions, Laricobius spp. larvae were recovered from caged branch samples, indicating that adults were not initially dislodged from branches when the cage treatments were applied in the fall. Data from those branches were excluded from the analyses and associated larvae were not counted as part of the total recovered.

At the completion of larval development, branch samples were removed, and HWA winter mortality and ovisac predation was assessed using criteria described above for the winter assessment. Winter mortality was not assessed in 2017 at TN1, TN3, NC1, and GA1 due to researcher error. In 2018, winter mortality was evaluated using a nondestructive visual analysis of ovisacs (based on size) both before and after placement of branches into the larval development funnels.

\subsection{Genetic analysis of Laricobius spp. recovered on study branches}

In Phase One, Laricobius larvae and adults recovered from study branches were identified as either L. nigrinus or L. rubidus using genetic protocols detailed in Davis et al. (2011). Briefly, these protocols involved amplification of the partial cytochrome oxidase subunit I (COI) gene. Sequencing reactions were then performed on purified PCR products using the BigDye Terminator kit (Applied Biosystems, Foster City, CA, and were analyzed on an Applied Biosystems 3730xl automated sequencer at the DNA Analysis Facility at Science Hill, New Haven, CT. Sequences were aligned and compared to known sequences for each species using DNASTAR Seqman Pro in LaserGene 8.0 (DNASTAR, Madison, WI) to determine species identification. Hybrids were not identified in Phase One due to unsuccessful attempts to amplify microsatellite loci.

In Phase Two, genetic analysis was performed on Laricobius spp. larval samples recovered from study branches to identify species as well as potential hybrids of $L$. nigrinus and $L$. rubidus. DNA was extracted from larvae using the Omega Bio-tek E.Z.N.A. ${ }^{\circledR}$ Tissue DNA kit and its associated protocols (Omega Bio-tek, Inc., Norcross, GA). Six microsatellite loci (LaGT01, LaCA04, LaGT07, LaGT13, LaCA14, LaCA16) (Havill et al., 2012; Klein et al., 2010) were amplified using techniques described in Klein et al. (2010). Fragments were analyzed using a 3730xl 96-Capillary Genetic Analyzer at the DNA Analysis Facility at Science Hill, New Haven, CT. Alleles were called using Geneious Prime 2019 (Biomatters, Inc., Newark, NJ). Hybrids were distinguished from $L$. nigrinus and $L$. rubidus using the software programs Structure 2.3.2 (Stanford University) and New Hybrids 1.1 (University of California).

\subsection{Statistical analyses}

The effects of treatment (cage, no-cage, or open-cage) on initial HWA density, percent HWA ovisac disturbance from Laricobius spp. adults, percent HWA winter mortality and cumulative percent HWA ovisac disturbance from Laricobius spp. adults and larvae were tested within sites using a one-way analysis of variance (ANOVA) at a significance level of $\alpha=0.05$. In Phase One, means for the three treatments were separated using Tukey's HSD. The distributions of each of the response variables (HWA density, winter mortality, and ovisac disturbance) were tested for normality using the goodness-of-fit Shapiro-Wilk W test statistic, or by analysis of skewness and kurtosis values (Thode, 2002; Zar, 2010). The following response variables were transformed to meet the assumption of normality: HWA density (logarithmic in Phase One, square root in Phase Two), percent winter mortality (arcsine, Phase One) and percent cumulative HWA disturbance (arcsine, Phase One). In Phase Two, a constant of 0.001 was added to both winter mortality and cumulative ovisac disturbance data to remove zeroes (Zar, 2010) and the data were Box-Cox transformed to meet the normality assumption. In Phase Two, Levene's test was used to assess homogeneity of variances between treatments. For those sites which had heterogeneity of variances, a Welch's ANOVA was used to assess differences between treatments. Means of untransformed data are reported in tables and figures. All statistical analyses were performed using JMP Pro 13.0 (SAS Institute, 2018).

\section{Results}

\subsection{Fall Assessment: Initial HWA densities}

HWA densities in the fall varied considerably among sites and years, with means ranging from 0.4 to $10.0 \mathrm{HWA} / \mathrm{cm}$ of new growth (Fig. 2A-I). There were no significant differences between the pre-assigned cage, no cage, and open cage branches at any of the sites or years (Table 2, Fig. 2A-I). This indicated that infestation levels on branches receiving the treatments were always similar at the time that they were applied. This similarity was important for avoiding bias and assessing treatment effects in the subsequent assessment periods.

3.2. Winter assessment (Phase One only): Adult Laricobius spp. predation of HWA sistens generation and HWA winter mortality

\subsubsection{Ovisac disturbance}

In 2015, mean HWA ovisac disturbance was 14\% (range: 0.3-43\%), $21 \%$ (range: $4-42 \%$ ), and $29 \%$ (range: $14-45 \%$ ) in cage, no-cage, and open-cage samples, respectively (Fig. 3A-I). There were significant effects of treatment on ovisac disturbance with no-cage and open-cage samples showing higher levels of predation at NC1 and higher levels on no-cage samples at TN2 when compared to caged branches (Table 2, Fig. 3E, G). In 2016, mean ovisac disturbance was 5\% (range: 0-28\%), $12 \%$ (range: $1-35 \%$ ), and $11 \%$ (range: $1-26 \%$ ) in cage, no-cage, and open-cage samples, respectively (Fig. 3A-I). There were significant effects of treatment on ovisac disturbance at both VA1 and VA2. Ovisac disturbance was higher on open-cage branches when compared to caged branches at VA1. At VA2 ovisac disturbance was higher on nocage and open-cage branches when compared to caged branches 

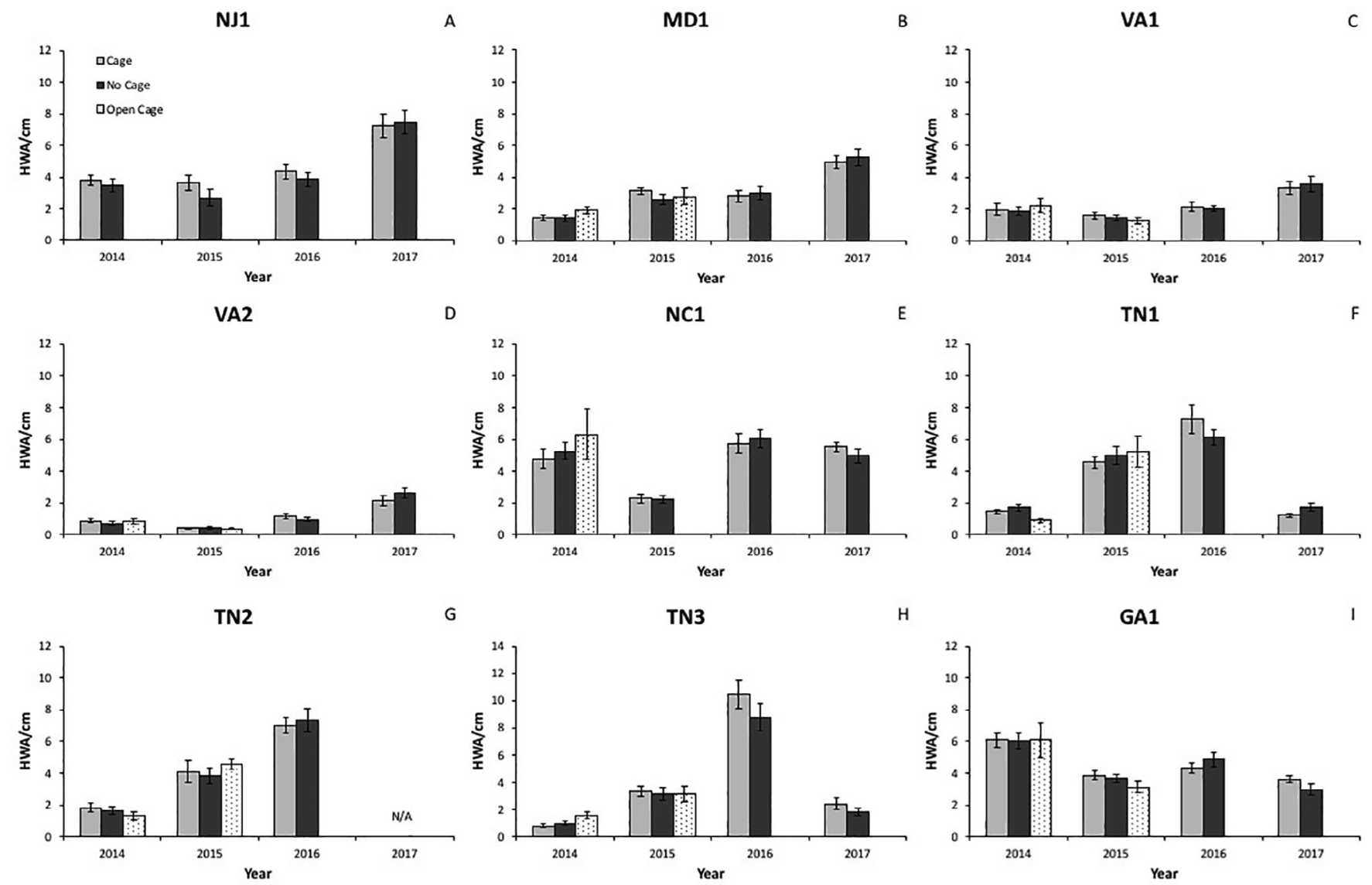

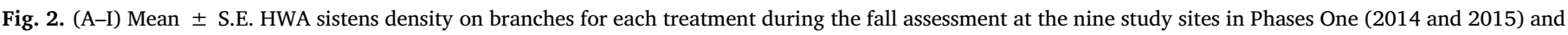
Two (2016 and 2017). N/A - Indicates data not collected at site.

(Table 2, Fig. 3C, D).

\subsubsection{Winter mortality}

In 2015, mean winter mortality among treatments at sites was $61 \%$ (range: 31-93\%) among sites (Fig. 4A-I). There was no significant effect of treatment on winter mortality in 2015 except at NC1 where there was a higher rate of HWA mortality in caged samples when compared to no-cage samples (Table 2, Fig. 4E). Similarly, overall mortality, (winter killed + disturbed HWA ovisacs) was measured at MD1, VA1, and VA2 in 2015 did not differ by treatment (Table 2,

Table 2

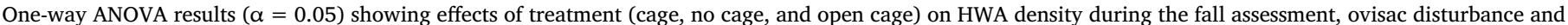
winter mortality during the winter assessment, and ovisac disturbance during the spring assessment in Phase One (2015 and 2016 ).

\begin{tabular}{|c|c|c|c|c|c|c|c|c|c|c|c|c|c|}
\hline \multirow[t]{2}{*}{ Year } & \multirow[t]{2}{*}{ Site } & \multicolumn{3}{|c|}{ Fall Assessment HWA/cm } & \multicolumn{3}{|c|}{ Winter Assessment \% Ovisac Disturbance } & \multicolumn{3}{|c|}{ Winter Assessment \% Winter Mortality } & \multicolumn{3}{|c|}{ Spring Assessment \% Ovisac Disturbance } \\
\hline & & $F$ & Df & $p$ & $F$ & Df & $p$ & $F$ & df & $p$ & $F$ & df & $p$ \\
\hline \multirow[t]{9}{*}{2015} & NJ1 & 0.53 & 1,36 & 0.47 & 0.004 & 1,31 & 0.95 & 0.54 & 1,31 & 0.47 & 2.8 & 1,26 & 0.11 \\
\hline & MD1 & 1.19 & 2,32 & 0.32 & $\mathrm{~N} / \mathrm{A}$ & N/A & N/A & $0.34^{*}$ & $2,18^{*}$ & $0.72^{*}$ & 0.0008 & 2,21 & 0.99 \\
\hline & VA1 & 0.34 & 2,32 & 0.71 & $\mathrm{~N} / \mathrm{A}$ & N/A & N/A & $0.34 *$ & $2,30 *$ & $0.72^{*}$ & 3.66 & 2,25 & 0.04 \\
\hline & VA2 & 0.61 & 2,33 & 0.55 & N/A & N/A & N/A & $0.23^{*}$ & $2,32^{*}$ & $0.79 *$ & 3.34 & 2,29 & 0.049 \\
\hline & NC1 & 0.24 & 2,25 & 0.79 & 13.69 & 2,24 & 0.0001 & 9.6 & 2,26 & 0.0001 & 28.6 & 2,25 & 0.0001 \\
\hline & TN1 & 2.77 & 2,32 & 0.078 & 2.19 & 1,27 & 0.15 & 0.17 & 1,27 & 0.68 & 3.74 & 2,27 & 0.037 \\
\hline & TN2 & 0.45 & 2,32 & 0.65 & 9.65 & 1,27 & 0.004 & 1.48 & 1,27 & 0.23 & 5.14 & 2,31 & 0.012 \\
\hline & TN3 & 2.93 & 2,32 & 0.068 & 3.52 & 1,25 & 0.073 & 1.32 & 1,25 & 0.26 & 2.7 & 2,30 & 0.0819 \\
\hline & GA1 & 0.014 & 2,32 & 0.99 & 0.12 & 2,32 & 0.89 & 0.45 & 2,32 & 0.64 & 4.91 & 2,32 & 0.014 \\
\hline \multirow[t]{9}{*}{2016} & NJ1 & 2.28 & 1,18 & 0.15 & 1.00 & 1,18 & 0.33 & 0.00 & 1,18 & 0.95 & $* *$ & $* *$ & $* *$ \\
\hline & MD1 & 1.30 & 2,33 & 0.29 & 0.50 & 2,21 & 0.62 & 1.86 & 2,21 & 0.18 & 58.80 & 2,16 & 0.00010 \\
\hline & VA1 & 0.46 & 2,31 & 0.64 & 4.39 & 2,30 & 0.02 & 0.62 & 2,30 & 0.55 & 11.74 & 2,31 & 0.00020 \\
\hline & VA2 & 0.31 & 2,32 & 0.74 & 6.12 & 2,31 & 0.01 & 0.66 & 2,31 & 0.52 & 0.46 & 2,29 & 0.64000 \\
\hline & NC1 & 0.01 & 1,26 & 0.93 & 3.64 & 1,26 & 0.07 & 0.51 & 1,26 & 0.48 & 16.20 & 1,24 & 0.00050 \\
\hline & TN1 & 0.08 & 2,12 & 0.93 & 1.70 & 2,12 & 0.22 & 1.01 & 2,12 & 0.39 & 2.48 & 2,12 & 0.13000 \\
\hline & TN2 & 0.56 & 2,12 & 0.59 & 1.03 & 2,12 & 0.39 & 0.68 & 2,12 & 0.52 & 11.33 & 2,12 & 0.00170 \\
\hline & TN3 & 0.11 & 2,12 & 0.90 & 2.28 & 2,12 & 0.15 & 0.25 & 2,14 & 0.78 & 2.00 & 2,12 & 0.18000 \\
\hline & GA1 & 0.79 & 2,31 & 0.46 & 1.62 & 2,31 & 0.21 & 1.94 & 2,31 & 0.16 & 7.29 & 2,30 & 0.00260 \\
\hline
\end{tabular}

*Overall mortality was recorded (ovisac disturbance + winter mortality)

**No disturbance observed 

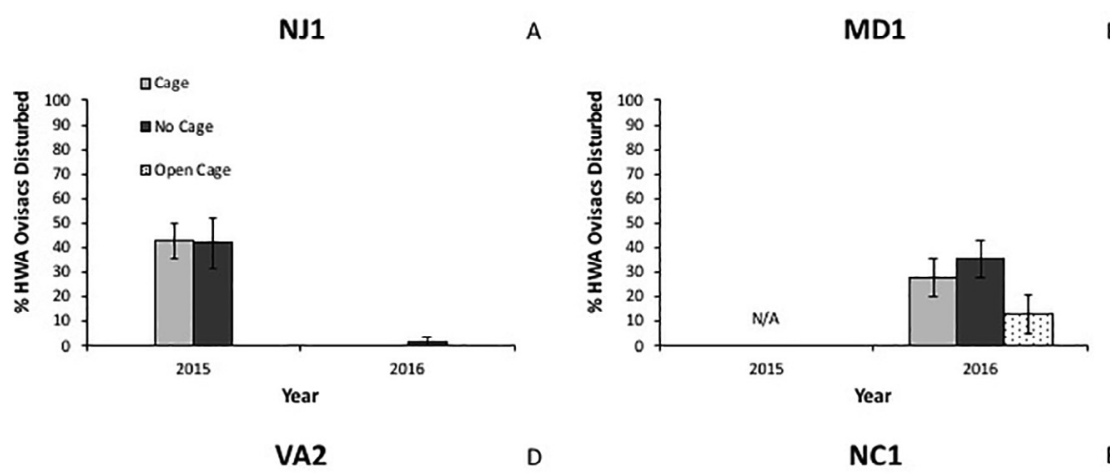

B

VA1 C

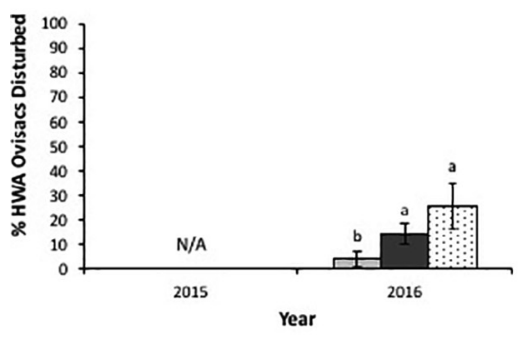

TN2

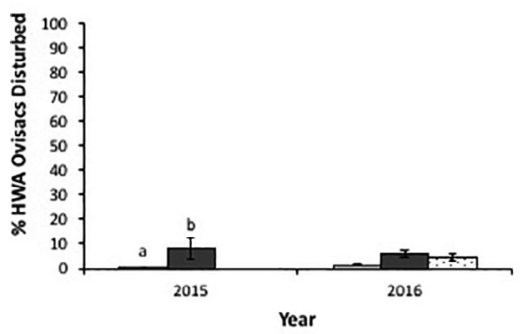

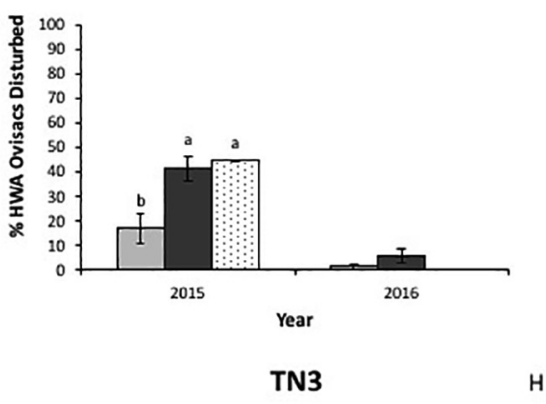

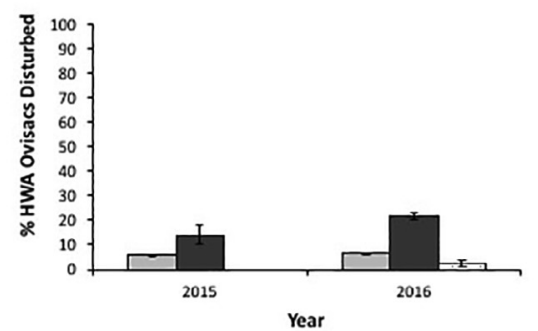

H

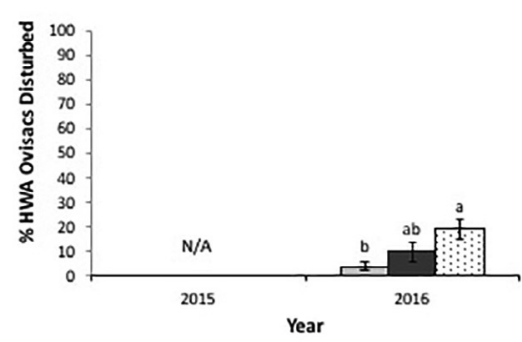

TN1
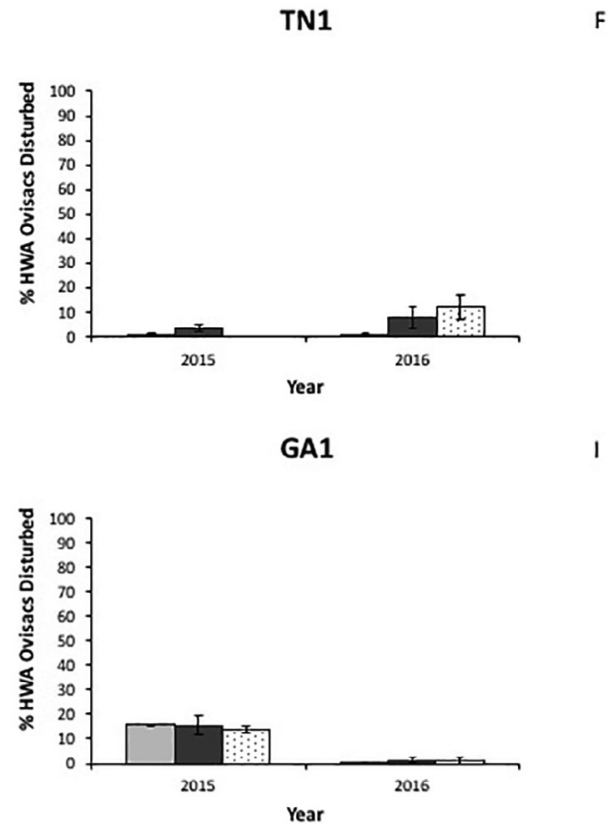

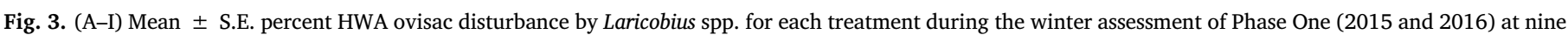

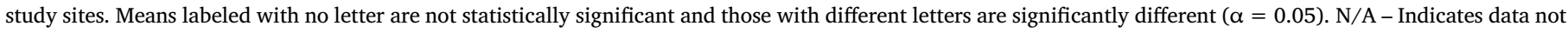
collected at site.

Fig. 4B, C, D). In 2016, mean winter mortality among treatments was $34 \%$ and varied considerably between sites (range: 14-97\%) (Fig. 4A-I). There were no significant effects of treatment on winter mortality in 2016 (Table 2, Fig. 4A-I).

3.3. Spring Assessment: HWA winter mortality (Phase Two only) and cumulative predation of HWA by adult and larval L. Nigrinus

\subsubsection{Winter mortality}

In 2017, mean HWA winter mortality among treatments at sites was 36\% (range: 2-92\%) (Fig. 4A-I). Treatment had a significant effect on winter mortality in 2017 with caged branches having higher levels of mortality at three of the four sites (NJ1, MD1 and VA2), but not at VA1 (Table 3, Fig. 4A, B, D). In 2018, mean HWA winter mortality among treatments at sites was 47\% (range: 20-84\%) (Fig. 4A-I). Treatment had a significant effect on winter mortality in 2018 with caged branches having higher levels of mortality at three of the eight sites (MD1, VA1 and VA2) (Table 3, Fig. 4B, C, D). Observed mean winter mortality was $67,41,34$, and $38 \%$ in USDA Plant Hardiness Zones $6 \mathrm{a}, 6 \mathrm{~b}, 7 \mathrm{a}$, and $7 \mathrm{~b}$ respectively during the four years of the study.

\subsubsection{Ovisac disturbance}

In 2015, mean percent disturbance of HWA ovisacs was 6\% (range: 0-16\%), 22\% (range: 0-48\%), and 8\% (range: 0-15\%) in cage, no-cage, and open-cage samples respectively (Fig. 5A-I). There was a significant treatment effect at VA1, VA2, NC1, TN2, and GA1, with no-cage or open-cage samples having higher levels of ovisac disturbance when compared to caged samples (Table 2, Fig. 5C, D, E, G, I). In 2016, mean percent disturbance of HWA ovisacs was 13\% (range: 0-56\%), 41\% (range: 0-93\%), and 48\% (range: 10-99\%) in cage, no-cage, and opencage samples, respectively (Fig. 5A-I). There were significant treatment effects observed at MD1, VA1, VA2, NC1, TN2, GA1, with higher levels of ovisac disturbance on no-cage or open-cage samples when compared to caged samples (Table 2, Fig. 5B, C, D, E, G, I). Mean percent disturbance at study sites in 2017 was $7 \%$ (range: 1-16\%) in caged samples and 55\% (range: $12-80 \%$ ) on no-cage samples (Fig. 5A-I). There was a significant treatment effect with no-cage branches having higher levels of ovisac disturbance than caged branches at all sites except VA1 (Table 3, Fig. 5A-I). In 2018, mean percent ovisac disturbance was $4 \%$ (range: $0-16 \%$ ) in caged samples, and 35\% (range: 9-57\%) on no-cage samples (Fig. 5A-I). There was a significant treatment effect, with nocage branches having higher levels of ovisac disturbance at all sites except NJ1 (Table 3, Fig. 5A-I).

\subsection{Laricobius spp. larval recoveries on study branches and genetic analysis}

\subsubsection{Phase One (2015 \& 2016)}

Laricobius spp. larvae were recovered at each of the nine sites during Phase One. Recoveries generally increased as percent ovisac disturbance increased. In 2015, Laricobius spp. larvae were recovered at eight of nine sites (Table 4, Fig. 5A-I). The mean percent $L$. nigrinus and L. rubidus recovered for all sites were 83 and 17\%, respectively 

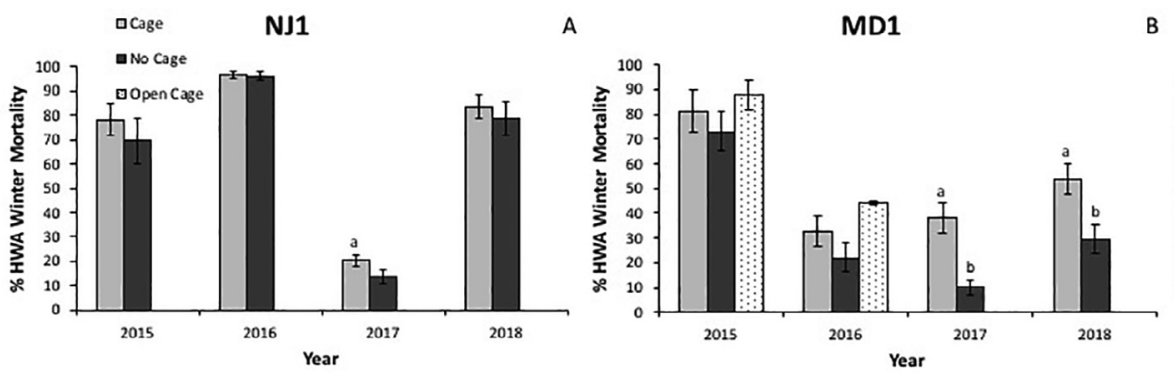

\section{B}

VA1

C
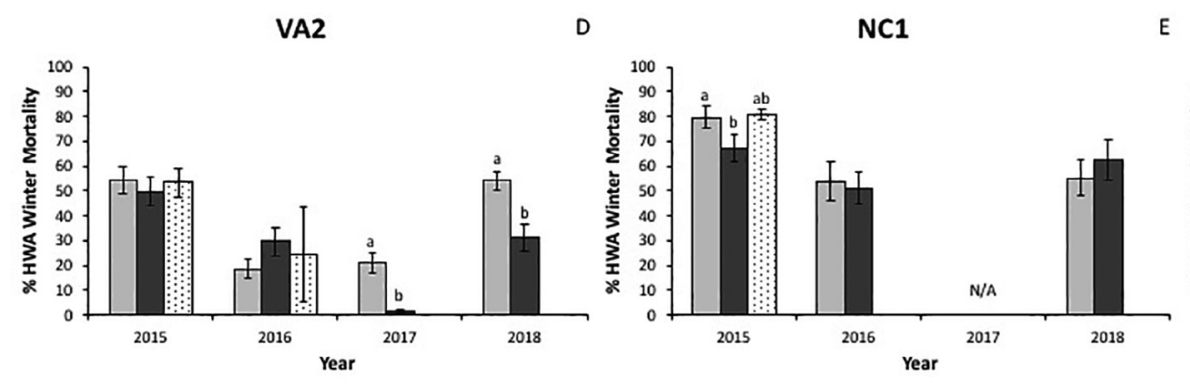

E

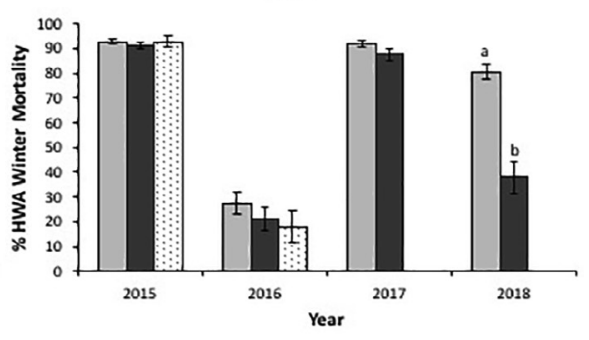

TN1
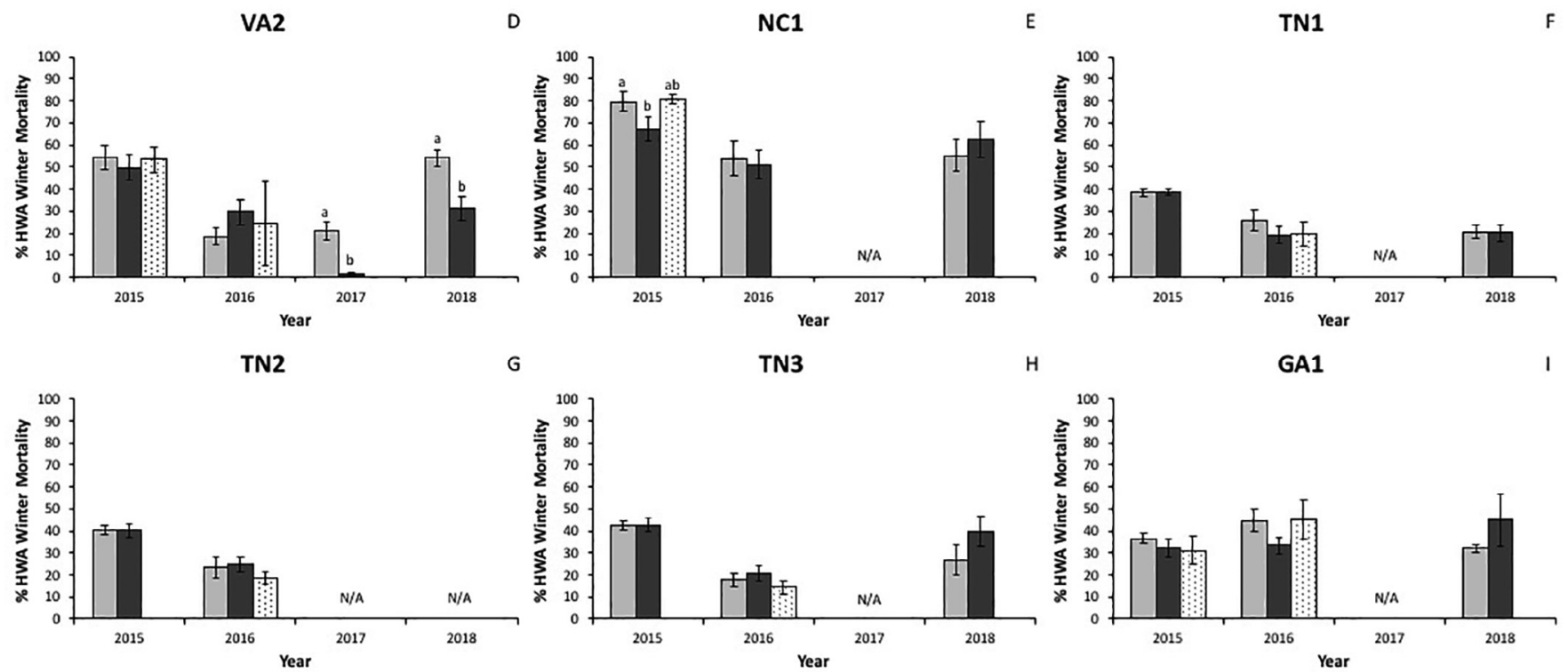

G TN3

H

GA1
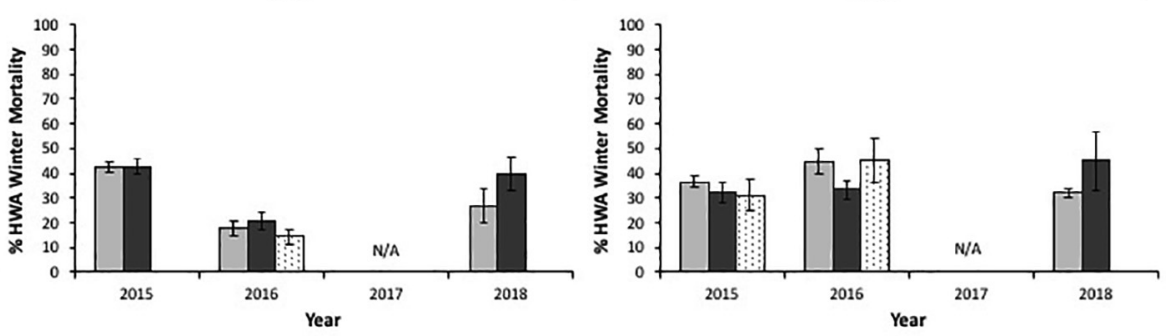

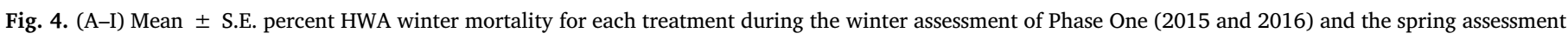

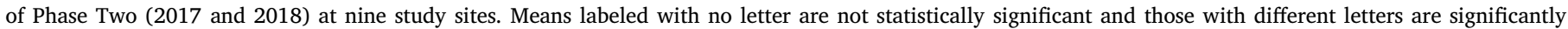
different $(\alpha=0.05)$. N/A - Indicates data not collected at site.

(Table 4). In 2016, larvae were recovered at eight of nine sites (Table 4, Fig. 5A-I). The mean percent $L$. nigrinus and $L$. rubidus recoveries for all sites was 90 and 10\%, respectively (Table 4).

\subsubsection{Phase Two (2017 \& 2018)}

Laricobius spp. larvae were also recovered at each of the nine sites during Phase Two. Recoveries generally increased as percent ovisac disturbance increased and were particularly robust in 2017 at all sites

Table 3

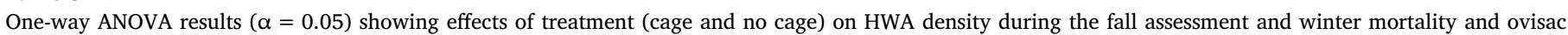
disturbance during the spring assessment in Phase Two (2017and 2018).

\begin{tabular}{|c|c|c|c|c|c|c|c|c|c|c|c|c|c|}
\hline \multirow[t]{2}{*}{ Year } & \multirow[t]{2}{*}{ Site } & \multicolumn{3}{|c|}{ Fall Assessment HWA/cm t } & \multicolumn{3}{|c|}{$\begin{array}{l}\text { Winter Assessment \% Ovisac } \\
\text { Disturbance }\end{array}$} & \multicolumn{3}{|c|}{ Spring Assessment \% Winter Mortality } & \multicolumn{3}{|c|}{ Spring Assessment \% Ovisac Disturbance } \\
\hline & & $F$ & $\mathrm{df}$ & $p$ & $F$ & Df & $p$ & $F$ & $\mathrm{df}$ & $p$ & $F$ & df & $p$ \\
\hline \multirow[t]{9}{*}{2017} & NJ1 & 0.67 & 1,34 & 0.42 & - & - & - & 5.32 & 1,34 & 0.0274 & 27.27 & $1,18.52$ & $0.0001^{\dagger}$ \\
\hline & MD1 & 0.15 & 1,28 & 0.70 & - & - & - & 20.21 & 1,28 & 0.0001 & 78.17 & 1,28 & 0.0001 \\
\hline & VA1 & 0.04 & 1,28 & 0.84 & - & - & - & 2.22 & 1,28 & 0.15 & 1.92 & 1,28 & 0.18 \\
\hline & VA2 & 1.24 & 1,26 & 0.28 & - & - & - & 49.63 & 1,26 & 0.0001 & 39.40 & 1,26 & 0.0001 \\
\hline & NC1 & 0.17 & 1,26 & 0.68 & - & - & - & - & - & - & 52.38 & $1,14.20$ & $0.0001^{\dagger}$ \\
\hline & TN1 & 0.90 & 1,22 & 0.35 & - & - & - & - & - & - & 240.76 & 1,22 & 0.0001 \\
\hline & TN2 & 0.05 & 1,26 & 0.82 & - & - & - & - & - & - & 42.94 & $1,13.86$ & $0.0001^{\dagger}$ \\
\hline & TN3 & 1.31 & 1,24 & 0.26 & - & - & - & - & - & - & 52.17 & $1,15.41$ & $0.0001^{\dagger}$ \\
\hline & GA1 & 0.76 & 1,24 & 0.39 & - & - & - & - & - & - & 65.43 & $1,14.12$ & $0.0001^{\dagger}$ \\
\hline \multirow[t]{9}{*}{2018} & NJ1 & 0.07 & 1,22 & 0.79 & - & - & - & 0.44 & 1,22 & 0.52 & 1.70 & $1,11.34$ & $0.22^{\dagger}$ \\
\hline & MD1 & 0.14 & 1,24 & 0.71 & - & - & - & 8.44 & 1,24 & 0.0078 & 22.61 & 1,24 & 0.0001 \\
\hline & VA1 & 0.05 & 1,20 & 0.82 & - & - & - & 26.74 & $1,12.19$ & $0.0002^{\dagger}$ & 72.65 & $1,14.92$ & $0.0001^{\dagger}$ \\
\hline & VA2 & 1.18 & 1,26 & 0.29 & - & - & - & 12.54 & $1,18.25$ & $0.0023^{\dagger}$ & 50.23 & $1,14.24$ & $0.0001^{\dagger}$ \\
\hline & NC1 & 1.5 & 1,28 & 0.24 & - & - & - & 0.17 & 1,28 & 0.69 & 14.28 & 1,14 & $0.0020^{\dagger}$ \\
\hline & TN1 & 3.85 & 1,28 & 0.06 & - & - & - & 0.17 & 1,28 & 0.69 & 13.21 & $1,16.22$ & $0.0011^{\dagger}$ \\
\hline & TN2 & - & - & - & - & - & - & - & - & - & - & - & - \\
\hline & TN3 & 0.93 & 1,22 & 0.35 & - & - & - & 2.42 & 1,22 & 0.13 & 18.03 & $1,16.21$ & 0.0006 \\
\hline & GA1 & 2.50 & 1,10 & 0.14 & - & - & - & 1.00 & 1,10 & 0.34 & 12.86 & 1,10 & 0.0050 \\
\hline
\end{tabular}

-Data not collected at site.

'Indicates analysis using Welch's ANOVA. 


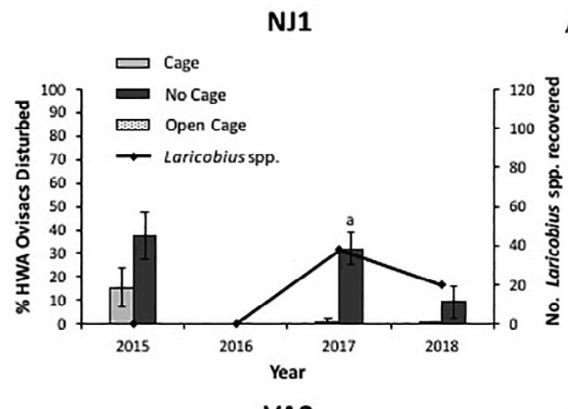

VA2

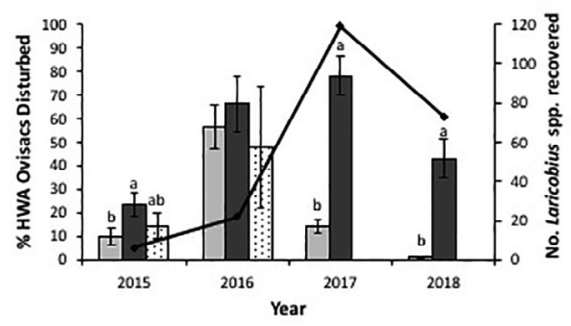

TN2

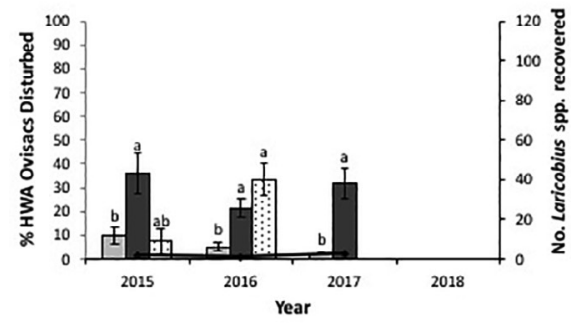

A

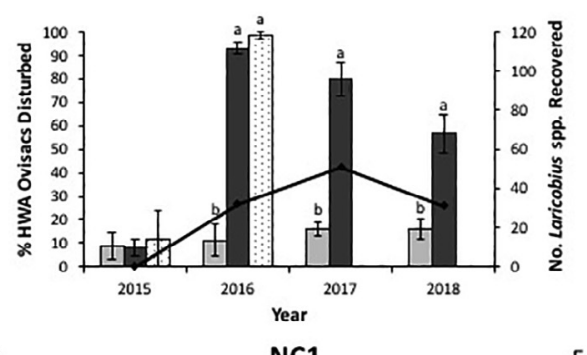

D

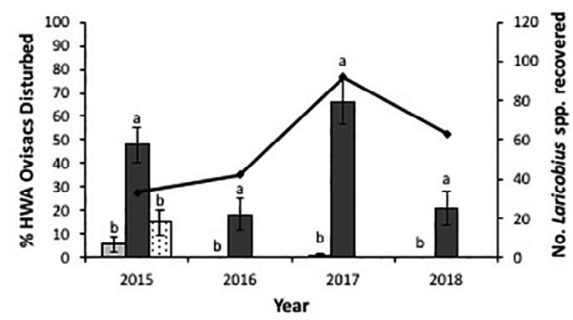

G

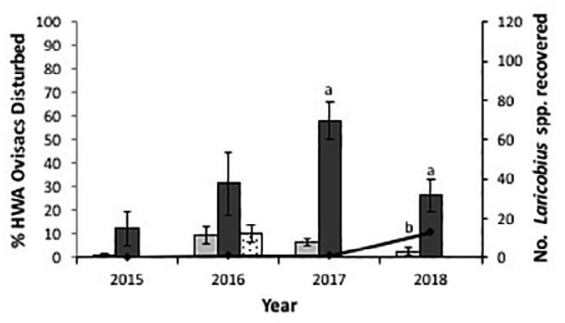

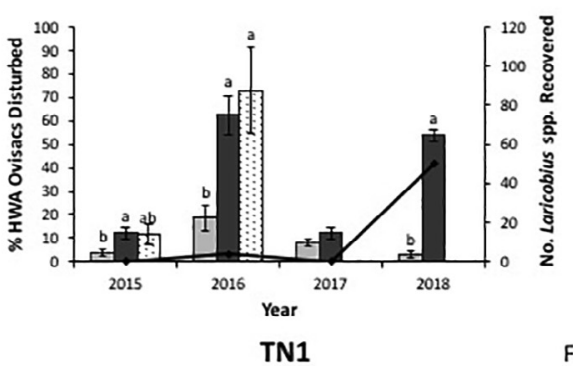

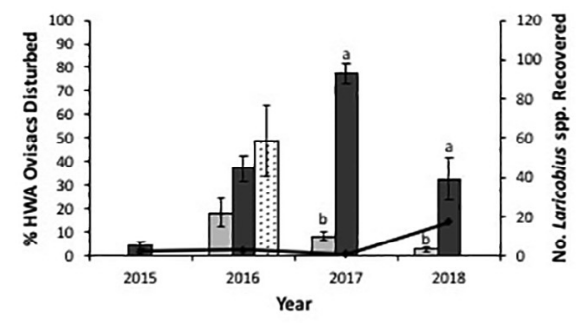

H

GA1

।

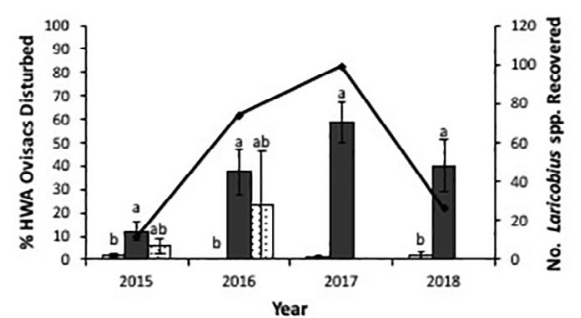

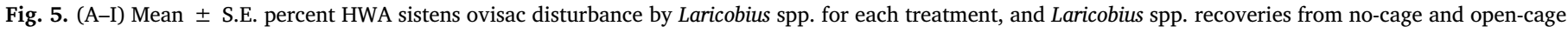

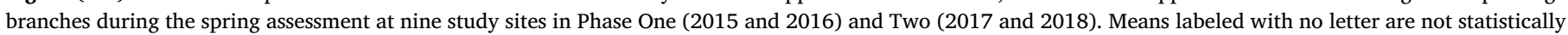
significant and those with different letters are significantly different ( $\alpha=0.05$ ). N/A - Indicates data not collected at site.

except for TN1, TN2, TN3, and at VA1 where HWA winter mortality was high. Microsatellite analysis revealed that L. nigrinus was the dominant species on study branches (Table 4). Laricobius rubidus and hybrids of $L$. rubidus and $L$. nigrinus were also recovered. In 2017, larvae were recovered at eight of nine sites (Table 4, Fig. 5A-I). The mean percent $L$. nigrinus, $L$. rubidus, and hybrid recoveries for all sites were 98.8, 0.8 , and $0.4 \%$, respectively. Regional occurrence of hybridization was minimal in 2017 with only one of nine sites having hybrid recoveries (Table 4). Larvae were recovered at eight of eight sites in 2018 (Table 4, Fig. 5A-I). The mean percent $L$. nigrinus, L. rubidus, and hybrid recoveries for all sites were $95.3,0.5$, and $4.2 \%$, respectively (Table 4). Four of eight sites had hybrids in 2018, however, only one site (TN3) had a notably high incidence of hybridization (Table 4).

\section{Discussion}

This four-year study represents the first assessment of the impact of L. nigrinus on HWA at multiple release sites and USDA Plant Hardiness Zones in the eastern U.S. This approach evaluated HWA ovisac disturbance as a measure of predation. The results demonstrated higher levels of HWA ovisac disturbance on branches where predators had access to prey (no-cage and open-cage treatments) compared to closed caged branches from which predators were excluded, and that L. nigrinus was likely the primary species responsible for the disturbance. Prior studies by Mausel et al. (2008) and Mayfield et al. (2015) that used sites VA2 and GA1 from this study, respectively, also demonstrated significantly higher levels of HWA ovisac disturbance on nocage branches when compared to those that were caged. The results of the present study are not only consistent with those previous studies, but also demonstrate a sustained predatory impact of $L$. nigrinus on HWA populations at multiple sites for multiple years. Our evaluations of impact assessment build on data observed in these prior studies and represent an important step in the development of the classical biological control program for HWA. Knowing the status of released predators and the degree to which they reduce densities of the target pest contributes to improved management decisions and provide justification for continued release and monitoring of this agent.

Pre-treatment HWA densities in the fall assessment varied greatly among sites and years over the duration of the study. However, they were consistently similar between treatments at each site which was ideal for analyzing treatment effects on those same branches during the winter and spring assessments. At most sites, HWA densities gradually increased after sustained low temperatures experienced during the polar vortex events in January 2014 and February 2015 (Fig. 2A-I). These temperatures likely caused high mortality to HWA populations (McAvoy et al., 2017b; Tobin et al., 2017). Laricobius nigrinus populations also declined at study sites after these events, however, it is not clear if this was due to low temperatures, or rather, a decrease in prey availability. In general, both HWA (Fig. 2A-I) and L. nigrinus (Fig. 5A-I) populations appeared to increase at study sites in the years following these polar vortex events. In contrast, at other sites such as GA1 and NC1, fall HWA density remained more consistent throughout the study. This consistency could be attributed to the southern latitude of these sites, which may have experienced less drastic winter temperatures than those seen at more northern latitudes (McAvoy et al., 2017b). Furthermore, some sites (TN1, TN3) experienced a sharp decline in fall 
Table 4

Total Laricobius spp. recoveries and resulting percentages of $L$. nigrinus or $L$. rubidus at each site in Phase One (2015 and 2016) using COI gene sequencing, and percentages of L. nigrinus, L. rubidus, and hybrids at each site in Phase Two (2017 and 2018) using microsatellite analysis.

\begin{tabular}{|c|c|c|c|c|c|}
\hline Year & Site & $\begin{array}{l}\text { No. Laricobius spp. } \\
\text { Successfully Tested }\end{array}$ & $\begin{array}{l}\% \text { L. } \\
\text { nigrinus }\end{array}$ & $\begin{array}{l}\% L . \\
\text { rubidus }\end{array}$ & \% Hybrid \\
\hline \multirow[t]{9}{*}{2015} & NJ1 & 0 & * & $*$ & - \\
\hline & MD1 & $* *$ & $* *$ & $* *$ & - \\
\hline & VA1 & 0 & * & $*$ & - \\
\hline & VA2 & 6 & $100 \%$ & $0 \%$ & - \\
\hline & $\mathrm{NC1}$ & 11 & $100 \%$ & $0 \%$ & - \\
\hline & TN1 & 0 & * & $*$ & - \\
\hline & TN2 & 0 & * & * & - \\
\hline & TN3 & 0 & * & $*$ & - \\
\hline & GA1 & 2 & $50 \%$ & $50 \%$ & - \\
\hline \multirow[t]{9}{*}{2016} & NJ1 & 0 & $*$ & $*$ & - \\
\hline & MD1 & 24 & $87 \%$ & $13 \%$ & - \\
\hline & VA1 & 2 & $100 \%$ & $0 \%$ & - \\
\hline & VA2 & 21 & $90 \%$ & $10 \%$ & - \\
\hline & NC1 & 31 & $77 \%$ & $23 \%$ & - \\
\hline & TN1 & 0 & * & * & - \\
\hline & TN2 & 0 & * & * & - \\
\hline & TN3 & 1 & $100 \%$ & $0 \%$ & - \\
\hline & GA1 & 25 & $96 \%$ & $4 \%$ & - \\
\hline \multirow[t]{9}{*}{2017} & NJ1 & 40 & $100 \%$ & $0 \%$ & $0 \%$ \\
\hline & MD1 & 25 & $96 \%$ & $0 \%$ & $4 \%$ \\
\hline & VA1 & $* *$ & $* *$ & $* *$ & $* *$ \\
\hline & VA2 & 30 & $100 \%$ & $0 \%$ & $0 \%$ \\
\hline & NC1 & 78 & $100 \%$ & $0 \%$ & $0 \%$ \\
\hline & TN1 & 1 & $100 \%$ & $0 \%$ & $0 \%$ \\
\hline & TN2 & 2 & $0 \%$ & $100 \%$ & $0 \%$ \\
\hline & TN3 & 0 & * & $*$ & $*$ \\
\hline & GA1 & 76 & $100 \%$ & $0 \%$ & $0 \%$ \\
\hline \multirow[t]{9}{*}{2018} & NJ1 & 16 & $100 \%$ & $0 \%$ & $0 \%$ \\
\hline & MD1 & 29 & $100 \%$ & $0 \%$ & $0 \%$ \\
\hline & VA1 & 30 & $100 \%$ & $0 \%$ & $0 \%$ \\
\hline & VA2 & 30 & $100 \%$ & $0 \%$ & $0 \%$ \\
\hline & NC1 & 60 & $93 \%$ & $2 \%$ & $5 \%$ \\
\hline & TN1 & 15 & $93 \%$ & $0 \%$ & $7 \%$ \\
\hline & TN2 & - & - & - & - \\
\hline & TN3 & 8 & $50 \%$ & $0 \%$ & $50 \%$ \\
\hline & GA1 & 25 & $96 \%$ & $0 \%$ & $4 \%$ \\
\hline
\end{tabular}

*Genetic analysis not successfully completed.

**Larvae not recovered at site.

-Data not collected at site.

HWA densities due to a lack of new growth on branches in 2017 (Fig. 2F, H). This decline may be related to density-dependent HWA population changes. Several studies have reported a negative HWA density-dependent response (McAvoy et al., 2017a; McClure, 1991; Sussky and Elkinton, 2014; Sussky and Elkinton, 2015). High-density HWA infestations on hemlock cause a deterioration in tree health, which can then in turn cause a subsequent decline in HWA populations. Although trees will often make a partial recovery and begin producing new shoot growth while HWA populations are low, HWA eventually returns, and their populations build again (McClure, 1991; Sumpter et al., 2018). Such feedbacks between hemlock health and adelgid density are presumed to have occurred at some of our sites after a rebound of HWA following the polar vortex events. Decreased HWA populations may have also been the result of certain abiotic factors unique to each site such as drought or excessively moist conditions, or temperature extremes in both summer and winter (McAvoy et al., 2017b), none of which were specifically monitored.

Winter temperatures experienced by the HWA sistens generation in the field setting proved to be an important factor in overall mortality of this insect, with levels as high as $97 \%$ at some sites. In Phase One (2015-2016), winter mortality did not differ among treatments at any of the sites with the exception of NC1 in 2015. The lack of significant differences between treatments suggests that the exclusion cages did not appear to influence the amount of HWA winter mortality. In Phase
Two (2017-2018), however, cage effects on winter mortality were apparent at four sites, with higher levels of winter mortality within cages compared to uncaged branches. Similar prior studies showed no effects of the use of exclusion cages on the temperature experienced on lower canopy branches (Lamb et al., 2005b; Lamb et al., 2006; Mausel et al., 2008). In this study, however, site specific factors such as variation of microclimates at branch locations or types of cage materials used, may have resulted in a cage effect. Although sleeve cages have been reported to affect branch microclimates by altering temperature, light intensity, and wind, research has shown that these effects are inconsistent and highly variable (Luck et al., 1988; Nelson and Rieske, 2014; Smith and De Bach, 1942). Within replicates of this study, effort was made to randomly assign treatments to branches with similar microclimatic conditions so it is difficult to identify a cause for the observed cage effect.

Overall mortality (winter mortality + ovisac disturbance) was calculated at MD1, VA1, and VA2 in 2015. Mortality at these sites did not differ among treatments, suggesting that feeding by adult Laricobius spp. during the winter was not having a measurable impact on HWA populations up to that point in the season at these three sites. Alternatively, it appears that winter mortality caused by cold temperatures may have contributed to most of the HWA mortality. It should be noted that the extreme cold temperatures experienced during the polar vortex event in 2015 had a greater impact on HWA mortality and may have also impacted $L$. nigrinus populations.

In the spring assessment, levels of ovisac disturbance were higher at a majority of sites in no-cage or open-cage samples during the four years of the study, indicating that Laricobius spp. larvae can have a significant impact on the sistens' ovisacs. Laricobius spp. larval recovery totals followed closely with the patterns of disturbance at many sites in most years with recoveries increasing as ovisac disturbance increased (Fig. 5A-I). With the exception of one coccinellid larva and one syrphid larva collected from study branches in Phase One during the laboratory larval development phase, no other predators were recovered on branches during the study. The minimal recovery of alternate predators suggests that disturbance of HWA ovisacs was primarily the result of feeding by Laricobius spp.

Laricobius spp. larval recoveries were low at all three TN sites in 2017, despite significant ovisac disturbance on the branches. While the low larval recoveries at these sites is puzzling, the ability of Laricobius spp. adults to create disturbance prior to larval abundance should not be discounted. Although Laricobius adults caused low levels of ovisac disturbance at some sites in Phase One, prior field cage studies showed significant impact by L. nigrinus adults on HWA nymphs during the preoviposition period (Lamb et al., 2005b). In 2017 at TN sites, early feeding on HWA nymphs by Laricobius spp. adults could have occurred prior to both oviposition and branches being removed for the spring assessment. It is possible that these adults dispersed from study branches to other areas within the site or tree and were therefore not recovered. Laricobius spp. has been shown to migrate vertically within trees after initial release on lower-canopy branches. Davis et al. (2012) reported that $L$. nigrinus beetles dispersed to the upper crown ( $>15 \mathrm{~m}$ ) for oviposition, and a large proportion of subsequent larvae were collected within these crown strata at some sites. Selection of treatment branches in the present study was limited to lower crown strata $(<2 \mathrm{~m})$ due to the challenges involved with the application of predator exclusion cages to branches in the upper crown. Alternatively, ovisac disturbance without recovery of Laricobius spp. larvae, may be explained by the sporadic occurrence of mechanical disturbance of ovisacs on branches. Although care was taken not to create disturbance during transport of branches to the laboratory, this disturbance could have been produced by branch-to-branch or branch-to-cage abrasion caused wind or animals in the field.

Results from the genetic analysis indicated that $L$. nigrinus was the primary Laricobius species present on study branches and therefore, most ovisac disturbance could be attributed their feeding activity. In 
Phase Two, subsamples of total larval recoveries were taken at some sites to reduce time and costs associated with the analysis. In both Phases One and Two, some samples could not be identified due to unsuccessful DNA extraction, or amplification of either loci or the COI gene during PCR. The fluctuation of hybridization levels observed between years could be a result of changes in $L$. nigrinus and L. rubidus prey abundance (Fischer et al., 2015), however, regional evaluations of PBA populations were not made during the study so it is not known if this was the cause of the fluctuation. While locally high levels of hybridization occurred at sites such as TN3 in 2018, hybridization levels in Phase Two (2\%), were lower than those reported in previous studies which ranged from 11 to $28 \%$ (Arsenault et al., 2015; Fischer et al., 2015; Havill et al., 2012; Mayfield et al., 2015; Wiggins et al., 2016). It should not be concluded, however, that hybridization levels are declining throughout the region because methods used in this study are limited in their ability to detect later generation hybrids. Some hybrids could have backcrossed with either L. nigrinus or L. rubidus and may not have been detected (Havill et al., 2012). It is apparent, however, that some introgression continues to occur between species at several sites used in this study, and although limiting, identification through the use of microsatellite techniques provides a general indication of Laricobius population distribution. In order to improve hybridization results and provide a better understanding of the impacts to populations of $L$. nigrinus and L. rubidus, additional microsatellite loci should be identified to make the analysis more powerful (Nathan Havill, personal communication, February 1, 2019).

This study provides a robust analysis of $L$. nigrinus impact that spans a variety of seasonal temperatures and USDA Plant Hardiness Zones. It suggests that throughout its introduced range, L. nigrinus disturbs a significant proportion of HWA sistens ovisacs in the spring, thereby reducing the number of eggs that contribute to the ensuing progrediens generation. In order to more fully understand the scope of $L$. nigrinus impact, future work should investigate how hemlock tree health is affected by $L$. nigrinus predation of HWA. The response of the HWA progrediens generation to predation of sistens and their ovisacs by $L$. nigrinus is also a critical component to understanding overall impact on HWA population dynamics. Data from this study indicates that HWA population densities remained stable or increased at many sites over time, suggesting that HWA populations rebounded via the progrediens generation following winter and spring mortality caused by cold temperatures and Laricobius predation. Although HWA populations appear to be able to recover from these mortality factors, it is reasonable to assert that $L$. nigrinus plays an important role in the overall predation of the sistens generation and progrediens eggs, and that effective management of this species in the eastern U.S. may only be possible with a suite of predators. This hypothesis is supported by the range of predators recovered during surveys on hemlock in the Pacific Northwest (Kohler et al., 2008). Evaluations investigating western strains of Leucopis argenticollis and L. piniperda in the eastern U.S. are in progress (Ross et al., 2011). These organisms may complement $L$. nigrinus by feeding during late-spring when Laricobius is in its inactive subterranean life stage (Motley et al., 2017). Further investigations of an additional predator, Laricobius osakensis Montgomery and Shiyake, which has been released and is known to have established at select sites in the eastern U.S. (Mooneyham et al., 2016; Toland et al., 2018), should also be made to evaluate their effectiveness singly or in conjunction with $L$. nigrinus. The data presented here support the continued use of $L$. nigrinus for biological control of HWA, with the ultimate goal of reducing damage to native hemlocks in the eastern U.S.

\section{Conclusions}

Our study demonstrated that $L$. nigrinus predation as well as winter temperatures both negatively impacted HWA ovisacs produced by the sistens generation. Laricobius nigrinus was the primary species recovered from study branches (compared to the native species, L. rubidus and hybrids of $L$. nigrinus and L. rubidus) and was therefore responsible for the observed predation on HWA ovisacs. Data from this study suggest that $L$. nigrinus likely plays a critical role in the overall management of HWA, however, additional predators are needed to help impact the progrediens generation and prevent population rebound after predation by Laricobius spp.

\section{CRediT authorship contribution statement}

Carrie S. Jubb: Investigation, Visualization, Formal analysis, Writing - original draft. Ariel R. Heminger: Investigation, Visualization, Formal analysis, Writing - original draft, Writing - review \& editing. Albert E. Mayfield: Conceptualization, Methodology, Investigation, Writing - review \& editing. Joseph S. El kinton: Conceptualization, Methodology, Writing - review \& editing. Gregory J. Wiggins: Investigation, Writing - review \& editing. Jerome F. Grant: Conceptualization, Methodology, Investigation, Writing - review \& editing. Jeffrey A. Lombardo: Investigation, Writing - review \& editing. Thomas J. McAvoy: Conceptualization, Methodology, Investigation, Writing - review \& editing. Ryan S. Crandall: Investigation, Writing - review \& editing. Scott M. Salom: Supervision, Conceptualization, Methodology, Writing - review \& editing.

\section{Declaration of Competing Interest}

The authors declare that they have no known competing financial interests or personal relationships that could have appeared to influence the work reported in this paper.

\section{Acknowledgements}

We gratefully acknowledge the assistance of Dr. Thomas Kuhar and Dr. Douglas Pfieffer (Virginia Tech) for review of this project, as well as Dr. Carlyle Brewster (Virginia Tech) for assistance with data analysis. We thank Dr. Nathan Havill (USDA Forest Service), Kari Stanley (Virginia Tech), and Melissa Fischer (Washington State Department of Natural Resources) for assistance with molecular protocols, as well as Mark Mayer (New Jersey Department of Agriculture), Scott Passwaters (James River State Park), Biff Thompson (Maryland Department of Agriculture), Jesse Webster (Great Smoky Mountains National Park), and the staff at Blackberry Farm (Tennessee) for site assistance. Thank you to Arthur Morgan School, Celo Community, and the Chattahoochee National Forest for permission to use sites in NC and GA. We are grateful to Natalie Morris, Kara Jeffries, Andy Dechaine, Ryan Mays, Ashley Toland, and James Wahls (Virginia Tech), Bryan Mudder and Andrew Tait (USDA Forest Service), David Bechtel, Philip Hensley, Elizabeth McCarty, Forest Palmer, Pat Parkman, and David Paulsen (University of Tennessee), and Peter Menzies, Marika Lapham, and Ivy Haas (University of North Carolina Asheville), for laboratory and field assistance. This work was funded under USDA Forest Service cooperative agreement 14-CA-11420004-028.

\section{References}

Arsenault, A.L., Havill, N.P., Mayfield, A.E., Wallin, K.F., 2015. Behavioral responses of Laricobius spp. and hybrids (Coleoptera: Derodontidae) to hemlock woolly adelgid and adelgid host tree odors in an olfactometer. Environ. Entomol. 44, 1562-1570.

Benton, E.P., Grant, J.F., Webster, R.J., Nichols, R.J., Cowles, R.S., Lagalante, A.F., Coots, C.I., 2015. Assessment of imidacloprid and its metabolites in foliage of eastern hemlock multiple years following treatment for hemlock woolly adelgid, Adelges tsugae (Hemiptera: Adelgidae), in forested conditions. J. Econ. Entomol. 108, 2672-2682. https://doi.org/10.1093/jee/tov241.

Brantley, S.T., Mayfield, A.E., Jetton, R.M., Miniat, C.F., Zietlow, D.R., Brown, C.L., Rhea, J.R., 2017. Elevated light levels reduce hemlock woolly adelgid infestation and improve carbon balance of infested eastern hemlock seedlings. For. Ecol. Manage. 385, 150-160. https://doi.org/10.1016/j.foreco.2016.11.028.

Brown, N.R., Clark, R.C., 1962. Studies of predators of the balsam woolly aphid, Adelges piceae (Ratz.) (Homoptera: Adelgidae) X. Field identification of Laricobius erichsonii Rosen. (Coleoptera: Derodontidae). Can. Entomol. 94, 191-193. https://doi.org/10. 
4039/Ent94191-2.

Cheah, C.A.S.-J., McClure, M.S., 1995. Exotic natural enemies of Adelges tsugae and their potential for biological control. In: Salom, S.M., Tigner, T.C., Reardon, R.C. (Eds.), Proceedings of the First Hemlock Woolly Adelgid Review. USDA Forest Service FHTET-96-10, pp. 103-112.

Clark, R.C., Brown, N.R., 1960. Studies of predators of the balsam woolly aphid, Adelges piceae (Ratz.) (Homoptera: Adelgidae), VII. Laricobius rubidus (Lec.) (Coleoptera: Derodontidae), a predator of Pineus strobi (Htg.) (Homoptera: Adelgidae). Can. Entomol. 92, 237-240. https://doi.org/10.4039/Ent92237-3.

Cowles, R.S., Montgomery, M.E., Cheah, C.A., 2006. Activity and residues of imidacloprid applied to soil and tree trunks to control hemlock woolly adelgid (Hemiptera: Adelgidae) in forests. J. Econ. Entomol. 99, 1258-1267. https://doi.org/10.1603/ 0022-0493-99.4.1258.

Davis, G.A., Havill, N.P., Adelman, Z.N., Caccone, A., Kok, L.T., Salom, S.M., 2011. DNA barcodes and molecular diagnostics to distinguish an introduced and native Laricobius (Coleoptera: Derodontidae) species in eastern North America. Biol. Control 58, $53-59$.

Davis, G.A., Salom, S.M., Brewster, C.C., Onken, B.P., Kok, L.T., 2012. Spatiotemporal distribution of the hemlock woolly adelgid predator Laricobius nigrinus after release in eastern hemlock forests. Agric. For. Entomol. 14, 408-418.

Fischer, M.J., Havill, N.P., Brewster, C.C., Davis, G.A., Salom, S.M., Kok, L.T., 2015. Field assessment of hybridization between Laricobius nigrinus and L. rubidus, predators of Adelgidae. Biol. Control 82, 1-6.

Foley, J.R., McAvoy, T.J., Dorman, S., Bekelja, K., Kring, T.J., Salom, S.M., 2019. Establishment and distribution of Laricobius spp. (Coleoptera: Derodontidae), a predator of hemlock woolly adelgid, within the urban environment in two localities in southwest Virginia. J. Integr. Pest. Manag. 10, 30. https://doi.org/10.1093/jipm/ pmz027.

Havill, N.P., Davis, G., Mausel, D.L., Klein, J., McDonald, R., Jones, C., Fischer, M., Salom, S., Caccone, A., 2012. Hybridization between a native and introduced predator of Adelgidae: An unintended result of classical biological control. Biol. Control 63, 359-369.

Havill, N.P., Foottit, R.G., 2007. Biology and evolution of Adelgidae. Annu. Rev. Entomol. $52,325-349$.

Havill, N.P., Montgomery, M.E., Yu, G.Y., Shiyake, S., Caccone, A., 2006. Mitochondrial DNA from hemlock woolly adelgid (Hemiptera: Adelgidae) suggests cryptic speciation and pinpoints the source of the introduction to eastern North America. Ann. Entomol. Soc. Am. 99, 195-203. https://doi.org/10.1603/0013-8746(2006) 099[0195:Mdfhwa]2.0.Co;2.

Havill, N.P., Shiyake, S., Galloway, A.L., Foottit, R.G., Yu, G.Y., Paradis, A., Elkinton, J., Montgomery, M.E., Sano, M., Caccone, A., 2016. Ancient and modern colonization of North America by hemlock woolly adelgid, Adelges tsugae (Hemiptera: Adelgidae), an invasive insect from East Asia. Mol. Ecol. 25, 2065-2080. https://doi.org/10.1111/ mec.13589.

Jetton, R.M., Whittier, W.A., Dvorak, W.S., Rhea, J.P., 2013. Conserved ex situ genetic resources of eastern and Carolina hemlock. Tree Planters Notes 56, 59-71.

Klein, J.L., Caccone, A., Havill, N.P., 2010. Polymorphic microsatellite loci for Laricobius nigrinus and L. rubidus (Coleoptera: Derodontidae), predators of the hemlock woolly adelgid. Mol. Ecol. Resour. 10, 751-754.

Koch, R.L., 2003. The multicolored Asian lady beetle, Harmonia axyridis: a review of its biology, uses in biological control, and non-target impacts. J. Insect Sci. 3, 32

Kohler, G.R., Stiefel, V.L., Wallin, K.F., Ross, D.W., 2008. Predators associated with the hemlock woolly adelgid (Hemiptera: Adelgidae) in the Pacific Northwest. Environ. Entomol. 37, 494-504.

Lamb, A.B., Montgomery, M.E., Vieria, L.C., Shiyake, S., Salom, S.M., 2011. Laricobius osakensis, a hemlock woolly adelgid predator from Japan. In: Onken, B., Reardon, C., Eds.), Implementation and Status of Biological Control of the Hemlock Woolly Adelgid. USDA Forest Service FHTET-2011-04, Morgantown, WV, pp. 90-96.

Lamb, A.B., Salom, S.M., Kok, L.T., 2005a. Guidelines for rearing Laricobius nigrinus Fender. In: Onken, B., Reardon, R., Proceedings of the Third Symposium on Hemlock Woolly Adelgid in the Eastern United States. USDA Forest Service FHTET-2005-01, pp. 309-318.

Lamb, A.B., Salom, S.M., Kok, L.T., 2005. Survival and reproduction of Laricobius nigrinus Fender (Coleoptera: Derodontidae), a predator of hemlock woolly adelgid, Adelges tsugae Annand (Homoptera: Adelgidae) in field cages. Biol. Control 32, 200-207. https://doi.org/10.1016/j.biocontrol.2004.09.016.

Lamb, A.B., Salom, S.M., Kok, L.T., Mausel, D.L., 2006. Confined field release of Laricobius nigrinus (Coleoptera: Derodontidae), a predator of the hemlock woolly adelgid, Adelges tsugae (Hemiptera: Adelgidae), in Virginia. Can. J. For. Res. 36, 369-375. https://doi.org/10.1139/x05-190.

Luck, R.F., Shepard, B.M., Kenmore, P.E., 1988. Experimental methods for evaluating arthropod natural enemies. Annu. Rev. Entomol. 33, 367-389. https://doi.org/10. 1146/annurev.en.33.010188.002055.

Mausel, D.L., Kok, L.T., Salom, S.M., 2017. Numerical response and impact of Laricobius nigrinus (Coleoptera: Derodontidae) on Adelges tsugae (Hemiptera: Adelgidae) in their native range. Environ. Entomol. 46, 544-551. https://doi.org/10.1093/ee/nvx078.

Mausel, D.L., Salom, S.M., Kok, L.T., Davis, G.A., 2010. Establishment of the hemlock woolly adelgid predator, Laricobius nigrinus (Coleoptera: Derodontidae), in the eastern United States. Environ. Entomol. 39, 440-448.

Mausel, D.L., Salom, S.M., Kok, L.T., Fidgen, J.G., 2008. Propagation, synchrony, and impact of introduced and native Laricobius spp. (Coleoptera: Derodontidae) on hemlock woolly adelgid in Virginia. Environ. Entomol. 37, 1498-1507.

Mayfield, A.E., Reynolds, B.C., Coots, C.I., Havill, N.P., Brownie, C., Tait, A.R., Hanula, J.L., Joseph, S.V., Galloway, A.B., 2015. Establishment, hybridization and impact of Laricobius predators on insecticide-treated hemlocks: exploring integrated management of the hemlock woolly adelgid. For. Ecol. Manage. 335, 1-10.
McAvoy, T.J., Mays, R., Salom, S.M., Johnson, N.G., 2017a. The effects of shade, fertilizer, and pruning on eastern hemlock trees and hemlock woolly adelgid. Forests 8 , 156. https://doi.org/10.3390/f8050156.

McAvoy, T.J., Régnière, J., St-Amant, R., Schneeberger, N.F., Salom, S.M., 2017b. Mortality and recovery of hemlock woolly adelgid (Adelges tsugae) in response to winter temperatures and predictions for the future. Forests 8, 21. https://doi.org/10. 3390/f8120497.

McClure, M.S., 1987. Biology and Control of Hemlock Woolly Adelgid, Bulletin 851 Connecticut Agricultural Experiment Station, New Haven, CT, pp. 1-9.

McClure, M.S., 1989. Evidence of a polymorphic life-cycle in the hemlock woolly adelgid, Adelges tsugae (Homoptera: Adelgidae). Ann. Entomol. Soc. Am. 82, 50-54.

McClure, M.S., 1991. Density-dependent feedback and population-cycles in Adelges tsugae (Homoptera: Adelgidae) on Tsuga canadensis. Environ. Entomol. 20, 258-264.

McClure, M.S., Cheah, C.A.S.-J., 1999. Reshaping the ecology of invading populations of hemlock woolly adelgid, Adelges tsugae (Homoptera: Adelgidae), in eastern North America. Biol. Invasions 1, 247-254. https://doi.org/10.1023/A:1010051516406.

Montgomery, M.E., Bentz, S.E., Olsen, R.T., 2009. Evaluation of hemlock (Tsuga) species and hybrids for resistance to Adelges tsugae (Hemiptera: Adelgidae) using artificial infestation. J. Econ. Entomol. 102, 1247-1254. https://doi.org/10.1603/029.102. 0351.

Mooneyham, K.L., Salom, S.M., Kok, L.T., 2016. Release and colonization of Laricobius osakensis (Coleoptera: Derodontidae), a predator of the hemlock woolly adelgid, Adelges tsugae. Northeast. Nat. 23, 141-150.

Motley, K., Havill, N.P., Arsenault-Benoit, A.L., Mayfield, A.E., Ott, D.S., Ross, D., Whitmore, M.C., Wallin, K.F., 2017. Feeding by Leucopis argenticollis and Leucopis piniperda (Diptera: Chamaemyiidae) from the western USA on Adelges tsugae (Hemiptera: Adelgidae) in the eastern USA. Bull. Entomol. Res. 107, 699-704. https://doi.org/10.1017/S0007485317000219.

Nelson, L.A., Rieske, L.K., 2014. Microclimatic variation within sleeve cages used in ecological studies. J. Insect Sci. 14, 1-5. https://doi.org/10.1093/jisesa/ieu029.

Onken, B., Reardon, C., 2011. An overview and outlook for biological control of hemlock woolly adelgid. In: Onken, B., Reardon, C. (Eds.), Implementation and Status of Biological Control of the Hemlock Woolly Adelgid. USDA Forest Service FHTET2011-04, Morgantown, WV, pp. 222-228.

Orwig, D.A., Foster, D.R., Mausel, D.L., 2002. Landscape patterns of hemlock decline in New England due to the introduced hemlock woolly adelgid. J. Biogeogr. 29, 1475-1487. https://doi.org/10.1046/j.1365-2699.2002.00765.x.

Ross, D.W., Gaimari, S.D., Kohler, G.R., Wallin, K.F., Grubin, S.M., 2011. Chamaemyiid predators of the hemlock woolly adelgid from the Pacific Northwest. In: Onken, B., Reardon, C. (Eds.), Implementation and Status of Biological Control of the Hemlock Woolly Adelgid. USDA Forest Service FHTET-2011-04, Morgantown, WV, pp. 97-106.

Salom, S.M., Kok, L.T., Lamb, A.B., Jubb, C.S., 2012. Laboratory rearing of Laricobius nigrinus (Coleoptera: Derodontidae): A predator of the hemlock woolly adelgid (Hemiptera: Adelgidae). Psyche 2012, 9. https://doi.org/10.1155/2012/936519.

SAS Institute, 2018. JMP Pro 13.0. Cary, NC

Smith, H.S., De Bach, P., 1942. The measurement of the effect of entomophagous insects on population densities of their hosts. J. Econ. Entomol. 35, 845-849. https://doi. org/10.1093/jee/35.6.845.

Sumpter, K.L., McAvoy, T.J., Brewster, C.C., Mayfield, A.E., Salom, S.M., 2018. Assessing an integrated biological and chemical control strategy for managing hemlock woolly adelgid in southern Appalachian forests. For. Ecol. Manage. 411, 12-19. https://doi org/10.1016/j.foreco.2018.01.018.

Sussky, E.M., Elkinton, J.S., 2014. Density-dependent survival and fecundity of hemlock woolly adelgid (Hemiptera: Adelgidae). Environ. Entomol. 43, 1157-1167. https:// doi.org/10.1603/EN13356.

Sussky, E.M., Elkinton, J.S., 2015. Survival and near extinction of hemlock woolly adelgid (Hemiptera: Adelgidae) during summer aestivation in a hemlock plantation. Environ. Entomol. 44, 153-159. https://doi.org/10.1093/ee/nvu007.

Thode, H.C., 2002. Testing for Normality. Marcel Dekker, New York, NY.

Tobin, P.C., Turcotte, R.M., Blackburn, L.M., Juracko, J.A., Simpson, B.T., 2017. The big chill: quantifying the effect of the 2014 North American cold wave on hemlock woolly adelgid populations in the central Appalachian Mountains. Popul. Ecol. 59, 251-258.

Toland, A., Brewster, C., Mooneyham, K.L., Salom, S.M., 2018. First report on establishment of Laricobius osakensis (Coleoptera: Derodontidae), a biological control agent for hemlock woolly adelgid, Adelges tsugae (Hemiptera: Adelgidae), in the eastern U.S. Forests 9, 13. 10.3390/f9080496.

USDA, 2012. USDA Plant Hardiness Zone Map, https://planthardiness.ars.usda.gov/ PHZMWeb/. United States Department of Agriculture, (accessed: October 2, 2018).

Vieira, L.C., McAvoy, T.J., Chantos, J., Lamb, A.B., Salom, S.M., Kok, L.T., 2011. Hos range of Laricobius osakensis (Coleoptera: Derodontidae), a new biological control agent of hemlock woolly adelgid (Hemiptera: Adelgidae). Environ. Entomol. 40, 324-332.

Vieira, L.C., Salom, S.M., Montgomery, M.E., Kok, L.T., 2013. Field-cage evaluation of the survival, feeding and reproduction of Laricobius osakensis (Coleoptera: Derodontidae), a predator of Adelges tsugae (Hemiptera: Adelgidae). Biol. Control 66, 195-203. https://doi.org/10.1016/j.biocontrol.2013.05.004.

Virginia Tech, 2019. HWA Predator Database, https://hiro.ento.vt.edu/pdb/index.php/ home/. Virginia Tech, (accessed: September 20, 2017).

Wallace, M.S., Hain, F.P., 2000. Field surveys and evaluation of native and established predators of the hemlock woolly adelgid (Homoptera: Adelgidae) in the southeastern United States. Environ. Entomol. 29, 638-644. https://doi.org/10.1603/0046-225X29.3.638.

Wantuch, H.A., Havill, N.P., Hoebeke, E.R., Kuhar, T.P., Salom, S.M., 2019. Predators associated with the pine bark adelgid (Hemiptera: Adelgidae), a native insect in 
Appalachian forests, United States of America, in its southern range. Can. Entomol. 151, 73-84. https://doi.org/10.4039/tce.2018.53.

Wiggins, G.J., Grant, J.F., Rhea, J.R., Mayfield, A.E., Hakeem, A., Lambdin, P.L.

Galloway, A.B.L., 2016. Emergence, seasonality, and hybridization of Laricobius nigrinus (Coleoptera: Derodontidae), an introduced predator of hemlock woolly adelgid (Hemiptera: Adelgidae), in the Tennessee Appalachians. Environ. Entomol. 45, 1371-1378.

Young, R.F., Shields, K.S., Berlyn, G.P., 1995. Hemlock woolly adelgid (Homoptera: Adelgidae) - stylet bundle insertion and feeding sites. Ann. Entomol. Soc. Am. 88, 827-835.

Zar, J.H., 2010. Biostatistical Analysis. Prentice-Hall/Pearson, Upper Saddle River, N.J.
Zilahi-Balogh, G.M.G., Broeckling, C.D., Kok, L.T., Salom, S.M., 2005. Comparison between a native and exotic adelgid as hosts for Laricobius rubidus (Coleoptera: Derodontidae). Biocontrol Sci. Technol. 15, 165-171.

Zilahi-Balogh, G.M.G., Kok, L.T., Salom, S.M., 2002. Host specificity of Laricobius nigrinus Fender (Coleoptera: Derodontidae), a potential biological control agent of the hemlock woolly adelgid, Adelges tsugae Annand (Homoptera: Adelgidae). Biol. Control 24 192-198. https://doi.org/10.1016/S1049-9644(02)00014-2.

Zilahi-Balogh, G.M.G., Salom, S.M., Kok, L.T., 2003. Development and reproductive biology of Laricobius nigrinus, a potential biological control agent of Adelges tsugae. BioControl 48, 293-306. 